\title{
Rockshelter Sedimentation in a Dynamic Tropical Landscape: Late Pleistocene-Early Holocene Archaeological Deposits in Kitulgala Beli-lena, Southwestern Sri Lanka
}

\author{
Nikos Kourampas, ${ }^{1,} *$ Ian A. Simpson, ${ }^{1}$ Nimal Perera, ${ }^{2,3}$ \\ Siran U. Deraniyagala, ${ }^{2}$ and W.H. Wijeyapala ${ }^{2}$ \\ ${ }^{1}$ School of Biological and Environmental Sciences, University of Stirling, \\ Stirling FK9 4LA, Scotland, UK \\ ${ }^{2}$ Sri Lanka Department of Archaeology, Excavation Branch, Sir Marcus \\ Fernando Mawatha, Colombo \%, Sri Lanka \\ ${ }^{3}$ School of Archaeology and Anthropology, A.D. Hope Building \#14, The \\ Australian National University, Canberra, ACT 0200, Australia
}

\begin{abstract}
Kitulgala Beli-lena, a rockshelter in gneiss in humid tropical southwestern Sri Lanka, was inhabited by Late Pleistocene-Early Holocene ( $>31,000-7880$ B.P.) hunter-gatherers who made geometric microliths and exploited rainforest resources. Micromorphological analysis of a ca. 3-m-thick succession of diamictic loams, clays, and breccia with cultural content suggests that relative contribution of episodic colluviation and roof fall, water seepage through joints and diverse human activity varied through time. Facies changes across the profile reflect monsoon weakening ca. 20,000-16,000 cal B.P. and abrupt intensification ca. 15,700 cal B.P., on the wane of the global Last Glacial Maximum (LGM). Post-depositional modification included clay, sesquioxide, and minor phosphate translocation; termite and other arthropod bioturbation; and clast weathering on the rockshelter floor. Human input (tools and tool-making refuse, reworked charcoal and associated combustion by-products) is markedly higher in sediments younger than ca. 15,700 cal B.P., suggesting intensification of site use immediately after the LGM. (C) 2009 Wiley Periodicals, Inc.
\end{abstract}

\section{INTRODUCTION}

Two centuries of archaeological enquiry have rendered caves and rockshelters the loci sacri of prehistoric research. Preserving unparalleled records of past human activity and its environmental context, cave sediments have been approached from diverse interpretive perspectives, aiming at inferring human behaviour on-site and linking deposition in enclosed sediment sinks with potentially correlative processes in the wider landscape (Gillieson, 1996; Woodward \& Goldberg, 2001; Goldberg \& Sherwood, 2006). The last 20 years, in particular, have furnished important advances

*Corresponding author; E-mail: nkouramp@staffmail.ed.ac.uk.

Geoarchaeology: An International Journal, Vol. 24, No. 6, 677-714 (2009)

(C) 2009 Wiley Periodicals, Inc.

Published online in Wiley Interscience (www.interscience.wiley.com). DOI:10.1002/gea.20287 
in the geoarchaeology of caves and rockshelters, encouraged by wider availability of new dating methods (AMS ${ }^{14} \mathrm{C}$, OSL) and the development of novel research protocols, including thin-section micromorphology and an array of geochemical techniques that complement traditional analytical procedures (Woodward \& Morley, 2008). Unlike earlier attempts to correlate flowstones and the coarser component of cave sediments with warm-and-wet/cold-and-dry climatic cycles, respectively (notably Laville, Rigaud, \& Sackett, 1980), recent approaches have concentrated on the finer, commonly allogenic, sediment content as a potential link between caves/rockshelters and their surrounding landscapes. Sediment records from rockshelters in the circum-Mediterranean and the Atlantic coast of Europe have been used to infer Late Quaternary climate change with a varying degree of success (Woodward 1997a, 1997b; Woodward \& Bailey, 2000; Courty \& Valverdú, 2001; Goldberg \& Sherwood, 2006), depending mainly on the temporal resolution and environmental sensitivity of each site (Woodward \& Goldberg, 2001). Deposits from rockshelters with active karstic drainage may reflect warm/cold and wet/dry climatic cycles, correlative with millennial-scale Late Quaternary climatic cyclicity inferred from regional highresolution records (Courty \& Valverdú, 2001; Karkanas, 2001; Woodward \& Goldberg, 2001). Correlation efforts, however, are often hampered by the fragmentary, episodic character of rockshelter sediment records and the possibility of phase differences between causes (change in regional climate and ecosystem) and response of the local rockshelter system (as discussed in detail by Woodward \& Goldberg, 2001).

Application of these novel approaches, nevertheless, has been largely restricted to the circum-Mediterranean and, to a somewhat lesser extent, Western Europe and North America. Despite their significance for filling lacunae in the narrative(s) of human evolution and cultural change (Anderson, 1997; Mercader, 2002; Barker, Reynolds, \& Gilbertson, 2005), cave and rockshelter sites from the humid tropics are relatively underrepresented in the geoarchaeological literature (Stephens et al., 2005, but with exceptions: Moeyersons, 1997; Mercader et al., 2003; Sémah et al., 2004; Gilbertson et al., 2005; Hunt, Gilbertson, \& Rushworth, 2007; Lewis, 2007, 2008; Barker et al., 2007). Moreover, and partly reflecting its Mediterranean and EuroAmerican biases, virtually all geoarchaeological literature on rockshelter deposits concentrates on limestone rockshelters. Large parts of the cratonic interiors of the southern continents, however, consist of high-grade metamorphic rocks (gneisses, amphibolites, charnockites) and associated granites. Polygenetic etching, leaching, and mechanical weathering of such rocks in tropical conditions (Thomas, 1994) have produced relatively small (m- to tens-of-m-sized) rockshelters, which often attracted prehistoric human activity. To our knowledge, there are only two detailed descriptions of sediments from such non-karstic rockshelters in the geoarchaeological literature (Cameroon: Moeyersons, 1997; Ituri rainforest, Congo: Mercader et al., 2003). These pioneering works do not include micromorphological information.

This account of the micromorphology and microstratigraphy of Late Pleistocene-Early Holocene (>31,000 to 7880 cal B.P.) archaeological deposits from Kitulgala Beli-lena, a rockshelter in humid tropical southwestern Sri Lanka, is the first description of microfacies from a tropical rockshelter in gneiss. Our work here has three objectives: 
- to complement and refine extant accounts of Late Pleistocene-Early Holocene hunter-gatherer behavior at an important tropical rockshelter site (Deraniyagala, 1992; Wijeyapala, 1997; Perera, in press);

- to document processes of site formation, including nonhuman- and humaninduced sediment deposition and post-depositional modification, and assess the impact of the latter on the taphonomic integrity of the site's archaeological record;

- to explore links between sediment deposition in the rockshelter and Late Quaternary shifts in the wider tropical landscape, resulting from the changing intensity of the predominant climatic driver in the region, the Southwestern Monsoon.

\section{Modern Humans in Late Pleistocene-Early Holocene Sri Lanka: Cultures and Habitats}

The island of Sri Lanka in the Indian Ocean (Figure 1) has yielded the richest and, so far, the earliest reliably dated record of anatomically modern human settlement in South Asia, with skeletal and cultural remains dating back to ca. 40,000 yr cal B.P. (Deraniyagala, 1992; Wijeyapala, 1997; Mellars, 2006; James, 2007; Perera, in press). In Sri Lanka, Late Pleistocene hunter-gatherers of anatomical affinities with the Wanniyala-aeththo (Vadda/Vedda) hunter-gatherers of historical times (Kennedy et al., 1987; Kennedy \& Deraniyagala, 1989; Kennedy, 1999; Hawkey, 2003) produced microlithic tools, shell beads, and other articles of personal ornamentation as early
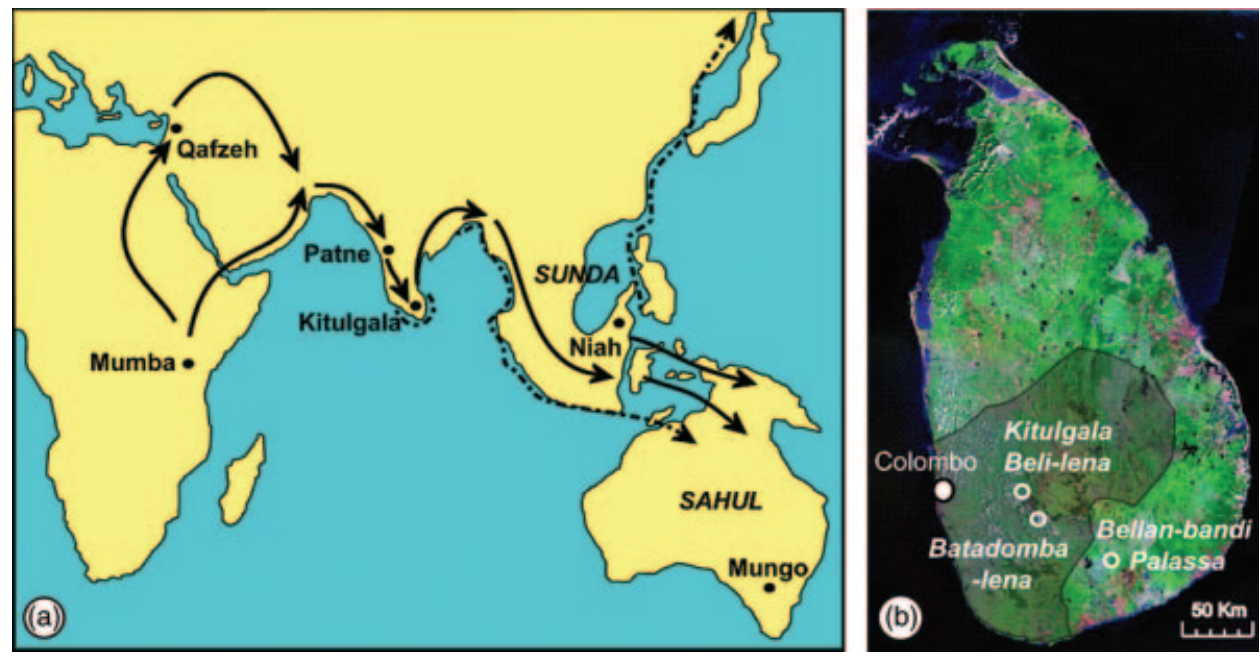

Figure 1. (a) Sri Lanka in the Late Pleistocene low-latitude world. Arrows show plausible routes of anatomically modern human dispersal from Africa to Eurasia and Australasia [solid line: Forster \& Matsamura, 2005, from Mellars, 2006; broken line: Oppenheimer's (2003) "beachcombers" route']. (b) Location of Kitulgala Beli-lena and two southern Sri Lankan sites mentioned in the text: Batadomba-lena, a rockshelter in the humid southwest, and Bellan-bandi Palassa, an open-air site in the dry southern lowlands. The shaded area receives over $2500 \mathrm{~mm}$ of rainfall annually. Satellite image from www.geology.com. 
as at least ca. 38,000 cal B.P. (Perera, in press). Associated with evidence for long networks of exchange, differentiated use of space, widespread use of ochre, and inferred burials in rockshelters, Sri Lanka's Late Pleistocene material culture is among the earliest manifestations of modern human behavior in South Asia (Deraniyagala, 1992; Wijeyapala, 1997; Mellars, 2006; James, 2007; Perera, in press).

This archaeological record, together with Sri Lanka's position halfway on the inferred southern route of anatomically modern human dispersal (Figure 1a) and paleobotanical evidence for severe Late Quaternary environmental change (Premathilake \& Risberg, 2003), locate the island's prehistory at the very center of current debates on Late Pleistocene human evolution, dispersal, and cultural change. For most of the Late Pleistocene, and as recently as ca. 7000 B.P., Sri Lanka was a southern extension of the Indian subcontinent (Deraniyagala, 1992; Gunatilaka, 2000). Recent research emphasizes the latter's significance as an important stepping stone on the journey of anatomically modern humans from Africa to Eurasia and Australasia (Oppenheimer, 2003). The Indian Subcontinent probably afforded a number of viable corridors for the peopling of the South Asian interior (Field, Petraglia, \& Lahr, 2007), thus functioning as a Late Pleistocene conduit for the settlement of the rest of the world. MtDNA and Y chromosome evidence from living South Asian populations provides further support for this inference (Endicott, Metspalu, \& Kivisild, 2007).

Fashioned by the interaction of mountainous relief and monsoonal climate, Sri Lanka's ecological mosaic of lowland, upland, and montane rainforest and semiarid grassland is well suited for the study of Late Pleistocene hunter-gatherer ecology in the humid tropics. Recent paleobotanical and isotopic studies of mire sediments in the wet highlands suggest that the island's environments changed repeatedly over the last 24,000 years in response to millennial and submillennial variations in the intensity of the Southwestern Monsoon (Premathilake \& Risberg, 2003). Monsoonal cyclicity was possibly driven by the combined effects of orbital forcing of the earth's climate and abrupt changes in sea surface temperature in the North Atlantic (Leushner \& Sirocko, 2003; Stott et al., 2002; Ivanochko et al,. 2005). Weakening of the Southwestern Monsoon during global Last Glacial Maximum (LGM) resulted in expansion of grassland at the expense of montane rainforest in the Sri Lankan Highlands. The end of the LGM was marked by renewed expansion of montane rainforest, driven by the reestablishment of the Southwestern Monsoon. Millennial-scale vegetation change in the Holocene is also thought to reflect monsoonal variations (Premathilake \& Risberg, 2003). This evidence from Sri Lanka's terrestrial record is in broad agreement with the pattern of Late Quaternary precipitation change inferred from offshore sediment proxies on the Indian continental shelf (Gupta, Anderson, \& Overpeck, 2003).

\section{Kitulgala Beli-lena: Environmental Setting and Archaeological Context}

Situated near the town of Kitulgala, in the Kegalle District of southwestern Sri Lanka, approximately $85 \mathrm{~km}$ from Colombo and the coast (Figure 1b), Beli-lena is a large (ca. $30 \times 15 \mathrm{~m})$, northwest-facing rockshelter on the banks of a small stream, some $60 \mathrm{~m}$ above present stream level (Figure 2). Beli-lena formed in gneiss bedrock, part of the high-grade metamorphic terrain (charnockite, ortho- and paragneiss, 

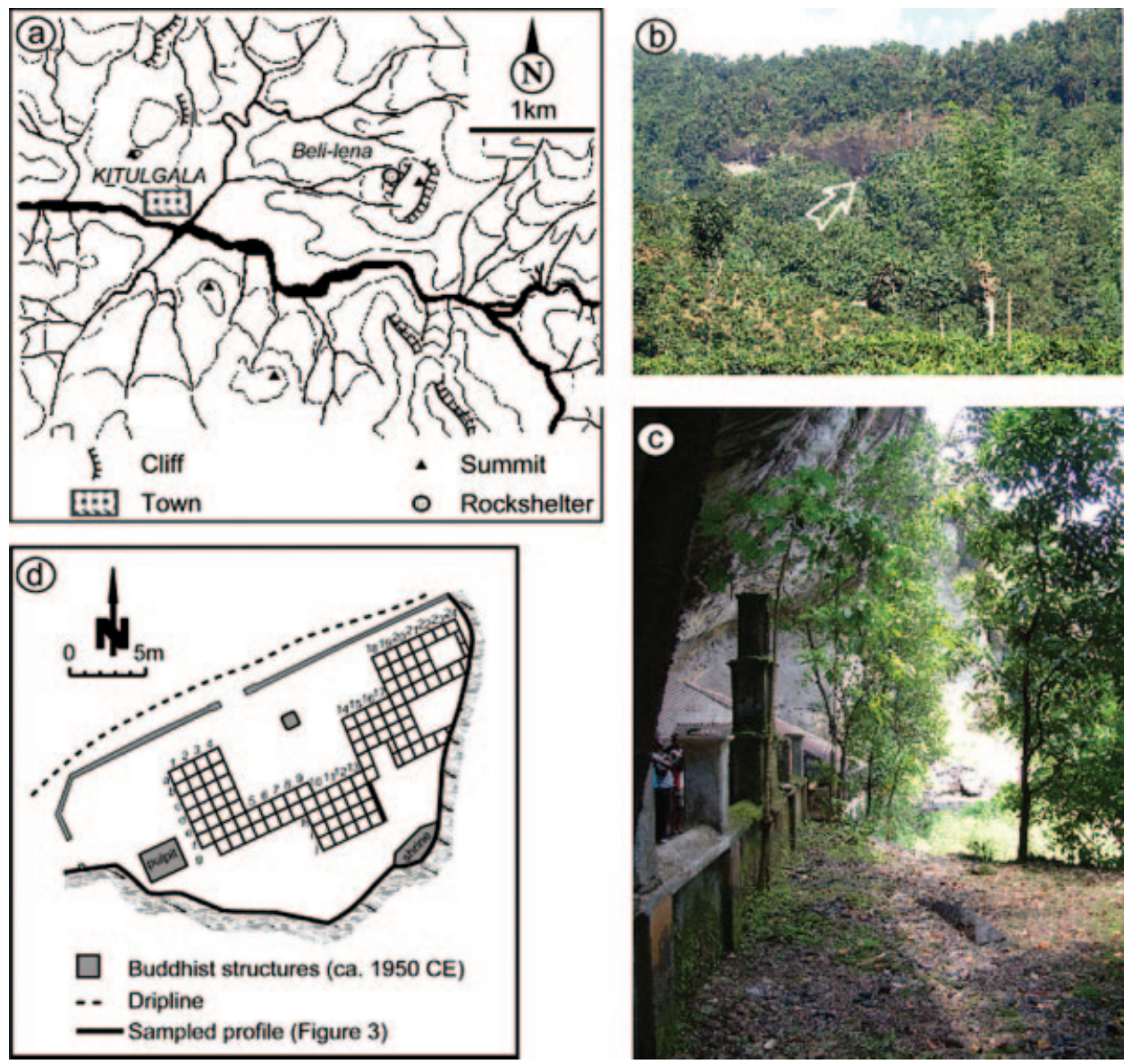

Figure 2. Clockwise from top left: (a) Relief, landscape, and drainage around Kitulgala Beli-lena. (b) Location of the rockshelter at the base of a steep cliff (arrow). (c) Entrance to the rockshelter (left), with later Buddhist structures. (d) Plan of the rockshelter with excavation grid (Wijeyapala, 1997).

metapegmatite) of the NNE-SSW trending Highland Complex (Cooray, 1984). As in the whole of southwestern Sri Lanka, the climate of the Kegalle District is humid tropical, with mean annual precipitation between 2500 and over $3500 \mathrm{~mm} /$ year (Domrös, 1974; Figure 1b). The dominant control over the regional climate is the Southwestern (summer) Monsoon, which brings the year's rainiest season from June to September. A less pronounced rainy season, from November to February, is caused by the Northeastern (winter) Monsoon. The NNW-SSE striking central mountain range concentrates Southwestern Monsoon rainfall on the windward, southwestern slopes and adjacent lowlands (Figure 1b). Away from sites of agricultural modification, vegetation mainly comprises dense, three-storey lowland evergreen forest dominated by species of Doona, Dipterocarpus, and Mesua (Gaussen et al., 1968). 
Beli-lena is one of the most important prehistoric sites in Sri Lanka, with evidence of human presence dating back to over 31,000 years B.P. (Kennedy et al., 1987; Deraniyagla, 1992; Wijeyapala, 1997; Perera, in press). Following a survey by P.E.P. Deraniyagala in 1960, Beli-lena was excavated by the Sri Lanka Archaeological Survey under the direction of Siran Deraniyagala (1978-1983) and, later, W.H. Wijeyapala (1986). These excavations sampled about $3 \mathrm{~m}$ of cultural deposits, spanning the time from over 31,000 to $7880 \mathrm{yr}$ cal B.P., as inferred from 25 radiocarbon dates (Deraniyagala, 1992; Wijeyapala, 1997; Perera, in press; see Figure 3). Excavated deposits contain an "enormous quantity of food remains, both faunal and floral" (Deraniyagala, 1992:315) and, in the upper layers, fragmentary remains of over 12

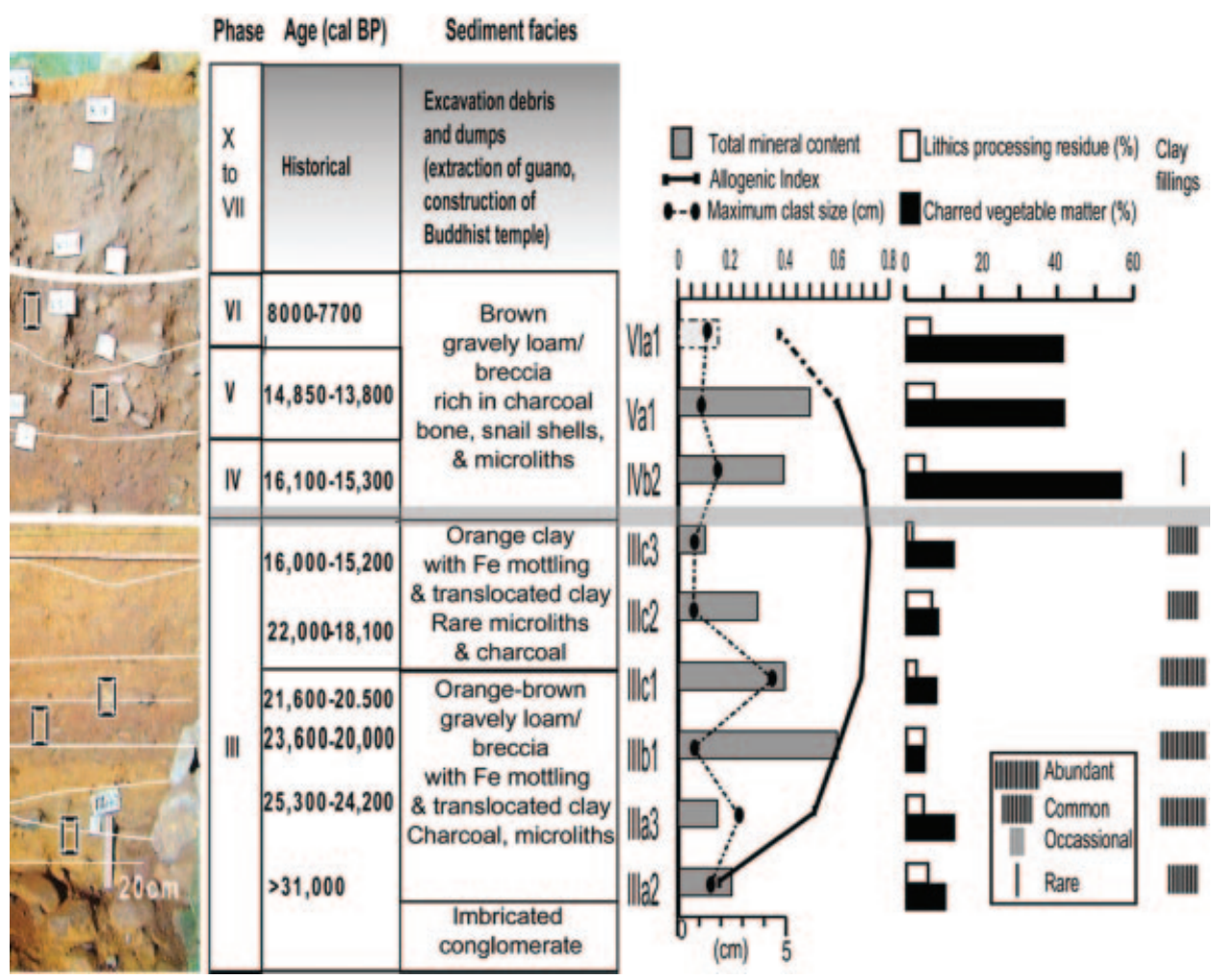

Figure 3. Stratigraphy, sediments, radiocarbon dates, and summary micromorphology of the sampled profile (note 20 -cm ruler for scale). Rectangles mark location of analyzed samples. Radiocarbon dates (Deraniyagala, 1992; Wijeyapala, 1997), quoted as 2 sigma ranges, were calibrated by Nimal Perera (in press) using CALIB 5.0.2. A sharp surface at the top of phase III forms the boundary between markedly different sediment facies, manifest as (1) change in color, lithology, total coarse mineral content (estimated frequency of mineral grains larger than $50 \mu \mathrm{m}$ ), relative contribution of inferred allogenic material (Allogenic Index), and identifiable human input (charred organics and possible lithics processing residue) and (2) as differences in post-depositional features (clay coatings, inferred phosphates, and degree of aggregation). This surface probably represents a significant shift in the system furnishing sediment to the rockshelter floor ca. 16,000-15,000 cal B.P. The sampled part of context VIa1 resulted from disintegration of a termite nest and, thus, does not register primary depositional processes. 
human individuals interpreted as fractional burials (Kennedy et al., 1987; Kennedy, 1990; Deraniyagala, 1992; Wijeyapala, 1997). Faunal remains are overwhelmingly dominated by monkeys, followed by giant squirrel, palm civet, flying squirrel, various other mammals, birds and reptiles, and large quantities of arboreal snails, notably Acavus spp. (Wijeyapala, 1997; Perera, in press). As at other Late Pleistocene rockshelter sites in southwestern Sri Lanka (Kourampas et al., 2008; Perera, in press), carbonized floral remains comprise a wide array of rainforest plants, including Canarium zeylanicum nuts, wild banana (Musa acuminata, M. balbisiana), and breadfruit (Artocarpus nobilis) (Kajale, 1989). Microlithic tools are present from the lower layers (ca. 24,700 cal B.P.) up, making Beli-lena one of the oldest reliably dated sites with microlithic industry in South Asia (Wijeyapala, 1997; Perera, in press). Beli-lena was resampled in 2005 as part of an ongoing reassessment of the prehistory of Sri Lanka within the broader context of anatomically modern human dispersal and the peopling of Australasia in the Late Pleistocene (Bulbeck et al., 2003; Perera, in press).

\section{Site Stratigraphy}

Previous excavation (Wijeyapala, 1997) and the 2005 fieldwork resolved the rockshelter sediment fill into 9 phases, each resolved further into higher-order contexts, as shown on Figure 3. The earliest deposit above weathered bedrock (phase II) is clast-supported conglomerate with well-rounded, imbricated pebbles. This alluvial sediment, of age older than ca. 31,000 B.P. and devoid of cultural content, may have been deposited by the stream that at present flows ca. $60 \mathrm{~m}$ below the level of the rockshelter entrance (Wijeyapala, 1997). Cultural content is present from phase III upwards. A sharp, low-relief stratigraphic boundary divides the stratigraphy in two parts: phase III below, from ca. 30,000 B.P. to 16,000 cal B.P. (bracketing the LGM), with orange brown clayey diamictic loams with low charcoal content and scattered microliths fining upward to clays; phases IV, V, and VI above, from ca. 15,700 to 7880 cal B.P., with dark brown breccia and diamictic loams with high charcoal content. The uppermost four phases (VII to X) comprise loose silty loams with variable charcoal content and a mixture of microliths with pottery fragments. These are interpreted as residue from the extraction of an estimated $3 \mathrm{~m}$ of guano-rich sediment, used as fertilizer at a nearby rubber plantation in colonial times (Wijeyapala, 1997). A sharp stratigraphic boundary demarcates the lower limit of historical disturbance, which at the sampled profile did not penetrate below Mid-Holocene levels (Figure 3). That the pre-Mid-Holocene stratigraphy appears to be relatively unaffected by recent human activity is not to imply that the sediment fill of Beli-lena represents a continuous record of the last ca. 30,000 years. Sharp intercontext boundaries, and the distribution of radiocarbon dates suggest episodic deposition, mainly by colluvial and roof fall processes (Wijeyapala, 1997) — an inference strengthened by the present micromorphological analysis.

\section{METHODOLOGY}

The 2005 sampling of the excavation trench aimed to assess microfacies variation and processes of deposition in Beli-lena. Nine undisturbed sediment samples were 
collected in Kubiena tins: seven from individual contexts and two across identified context boundaries (Figure 3). Thin sections were manufactured at the University of Stirling Thin Section Micromorphology Laboratory following standard procedures of resin impregnation, curing and slicing (http://www.thin.stir.ac.uk/ methods.html). Thin section descriptions were undertaken using plane polarized (PPL), cross-polarized (XPL), and oblique incident light (OIL) at a range of magnifications $(\times 10-\times 400)$. Standard visual aids were employed for semiquantitative estimation of groundmass components and pedofeatures (Bullock et al., 1985; Courty, Goldberg, \& Macphail, 1989; Stoops, 2003). Our point counting procedure was a modification of standard techniques described in the petrological/pedological literature (e.g., Harwood, 1988): A 0.5-cm-square grid on clear acetate was superimposed on covered thin sections and frequencies of designated particle categories (unweathered rock fragments, saprolith fragments, reworked pedogenic fragments, sediment intraclasts, possible lithics processing refuse, charcoal, and other charred organic matter) of size above $100 \mu \mathrm{m}$ were counted until a minimum total number of 300 counts was reached; individual particles that fell in more than one grid square were only counted once.

\section{MICROMORPHOLOGY AND MICROSTRATIGRAPHY}

The sampled profile comprises heterogeneous, diamictic pebbly sandy loams, breccias, and pebbly clay with variable cultural content, as shown in Figure 3. At a microscopic level, sediment facies diversity is manifest mainly as differences in color, degree of aggregation, internal organization of the sediment (microstructure and distribution of coarse in relation to fine particles), coarse mineral and charcoal content, relative intensity of bioturbation, and presence or absence of translocated clay. The main micromorphological characteristics of each sampled stratigraphic unit are summarized in Tables I and II. Significant aspects of compositional variation are highlighted in Figure 3, which summarizes quantitative and semiquantitative evidence for the relative abundance of human input and coarse mineral content across the sampled profile.

\section{General Micromorphological Characteristics of Kitulgala Beli-lena Deposits}

The sampled deposits are characterised by a number of common features (Tables I, II, Figures 4, 5), reflecting bedrock lithology, dominant processes of deposition (roof fall and colluviation), the geochemical environment of active ferrallitic weathering in and around the rockshelter, and micromorphologically visible activities of its Late Pleistocene human occupants.

\section{Groundmass: Rock Fragments and Reworked Soil Particles}

Coarse mineral content comprises rock fragments, quartz, and various other minerals, including minerals unstable in conditions of prolonged humid tropical weathering (e.g., feldspars, amphiboles, pyroxenes, mica), opaque minerals (probably 


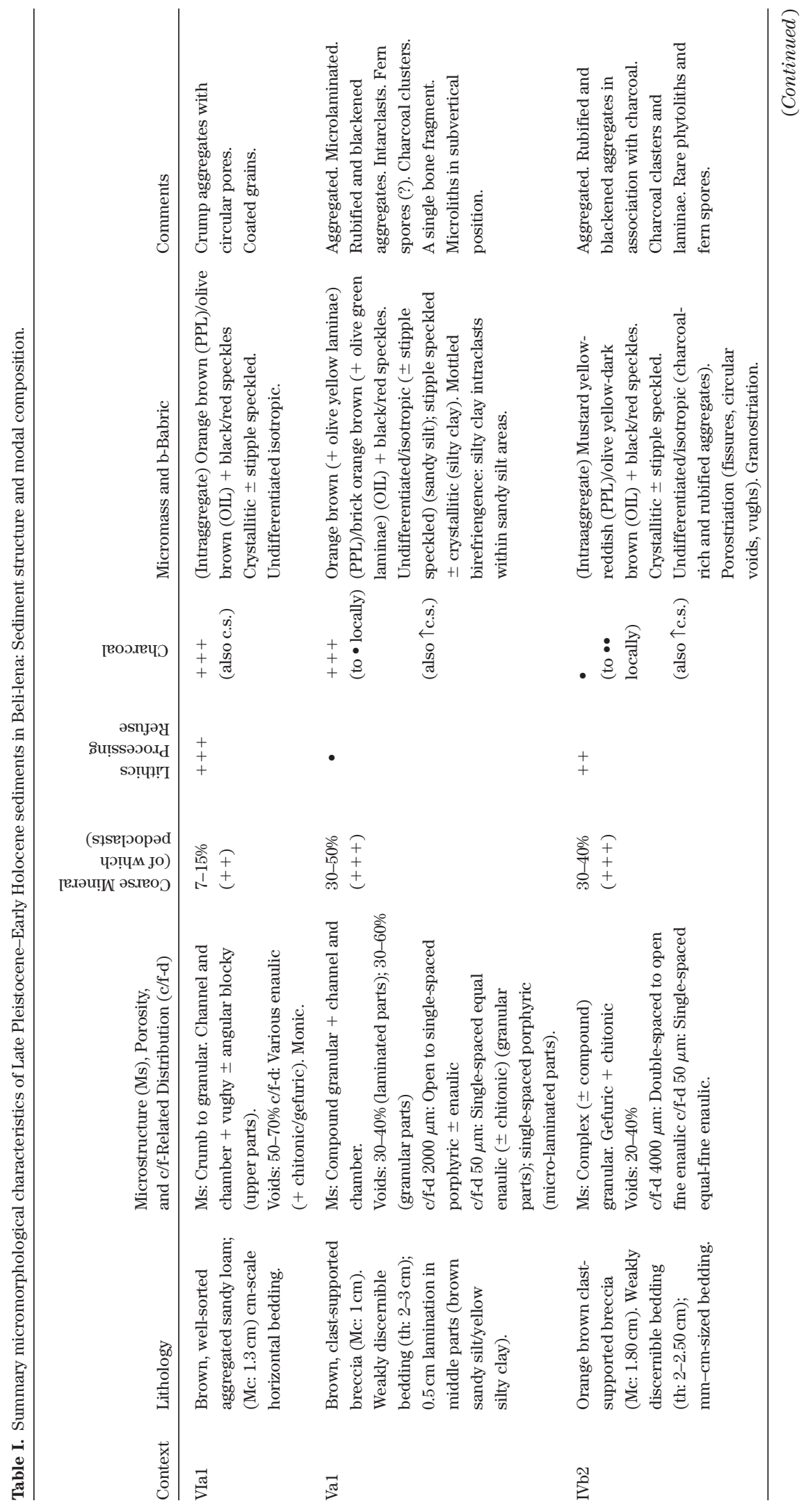




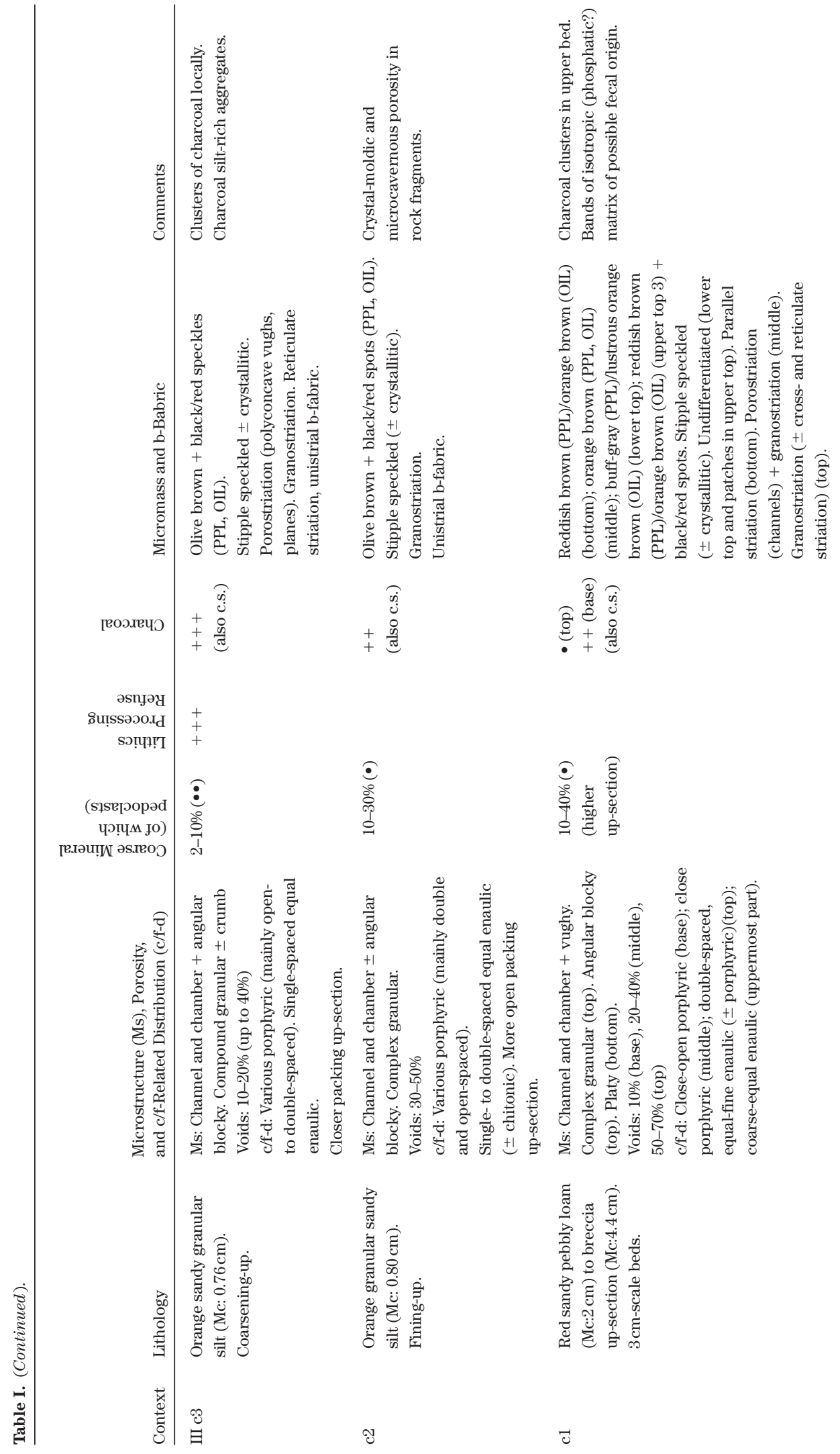




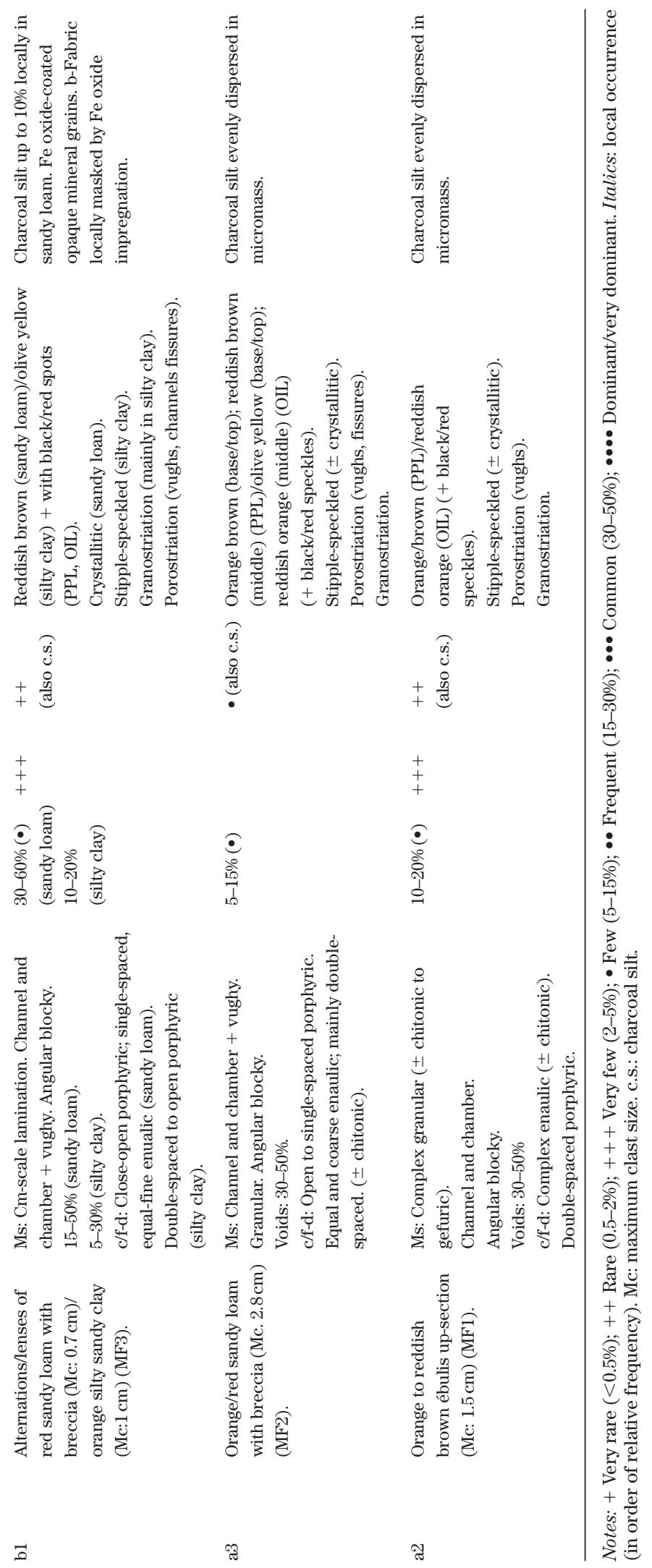




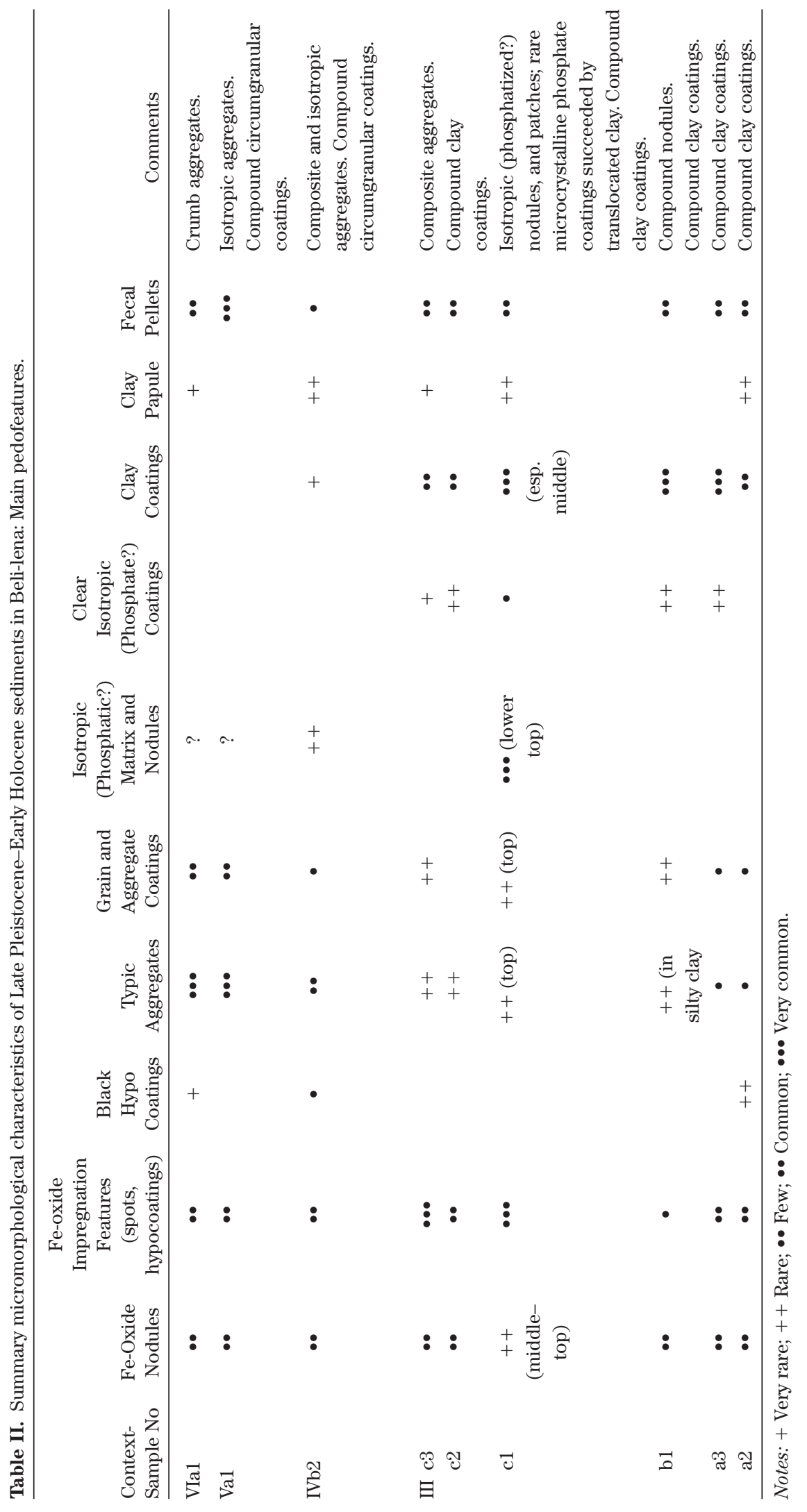



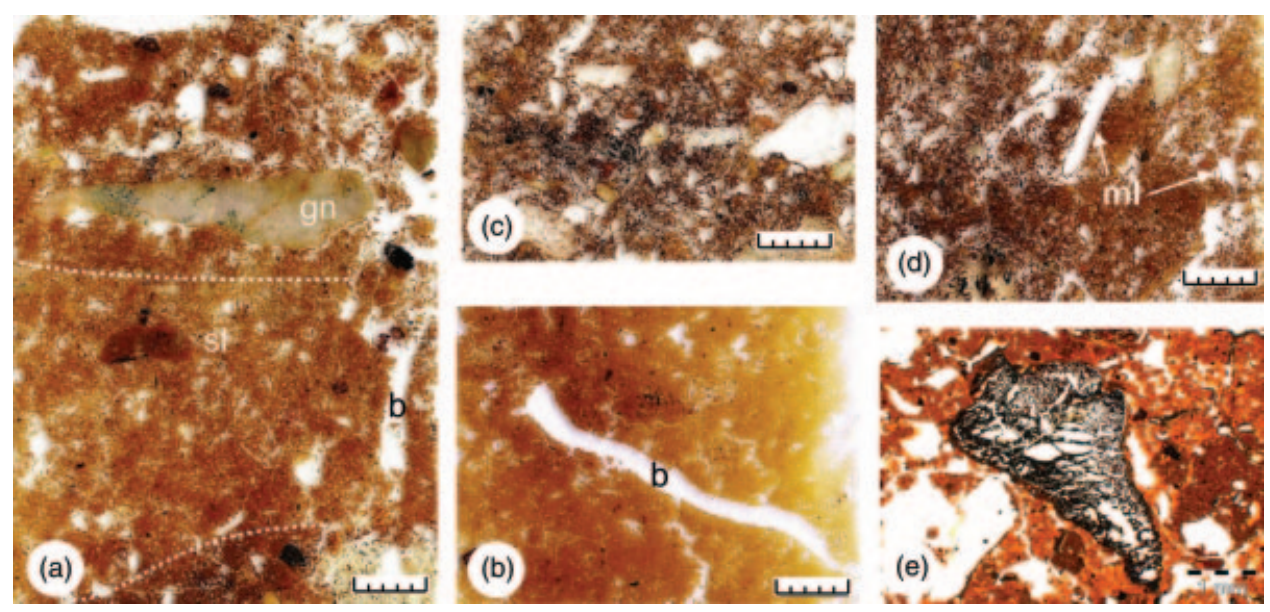

Figure 4.(a) Diamictic pebbly loam from the lower part of phase III (context IIIb1). Broken lines mark sedimentary surfaces. gn: gneiss; sl: saprolith; b: arthropod burrow. The zone $1-1.5 \mathrm{~cm}$ underneath the gneiss pebble contains isotropic (probably phosphatic) matrix. (b) Clay from the upper part of phase III (context IIIc3). b: arthropod burrow. (c) Charcoal-rich, closely packed breccia from phase IV (context IVb2). (d) Sandy pebbly loam with charcoal and microliths (ml) from phase V (context Va1). Note the subvertical position of microliths. (e) Wood charcoal fragment from lower part of phase III (context IIIa2). Also note iron oxide impregnation of micromass (dark rim: iron oxide hypocoatings; dark areas: incipient iron oxide nodules).

ilmenite and/or magnetite) and various iron oxide- and/or gibbsite-rich clasts, interpreted as reworked fragments of older tropical weathering mantle (cf. Delvigne, 1998). Coarse mineral content varies widely across the sampled profile, from $2-10 \%$ (silty clay in IIIc3) to 50-60\% (breccia in IIIb1, IVb2) (Table I; Figures 3, 4, 5). Clastrich and clast-poor contexts are separated by sharp depositional boundaries. Rock fragments include a mixture of relatively unweathered metamorphic lithologies (leucocratic gneiss/granitoid, quartz-biotite-garnet gneiss, charnockite) and altered rock fragments. The latter are characterized by pervasive alteration of alkali feldspars and plagioclase to kaolinite, other clay minerals or gibbsite, secondary porosity generated by dissolution of silicates (amphibole, pyroxene, and other minerals), and iron oxide deposition in resulting pore space. Locally such crystal-moldic pores, lined with open boxwork of clay and iron oxides, amount to up to 30-50\% of grain surface (e.g., Figure 5d). A further category of multimineral fragments includes well to moderately rounded particles of iron oxide with sand- to silt-sized etched quartz grains floating in an iddingsite matrix. These are interpreted as reworked ferricrete (referred to occur extensively in the wet lowlands of southwestern Sri Lanka; Bremer et al., 1981; Bremer, 1985; Deraniyagala, 1992; Figure 5c). Relative frequency of these allogenic pedoclasts varies significantly across the profile (Figure 3 ).

In addition to fragments of bedrock and indurated soil horizons, Beli-lena sediments contain variable quantities of yellow to red pedoclasts, with angular, medium sand-sized quartz grains in porphyric distribution within clayey micromass. Iron 
KOURAMPAS ET AL.
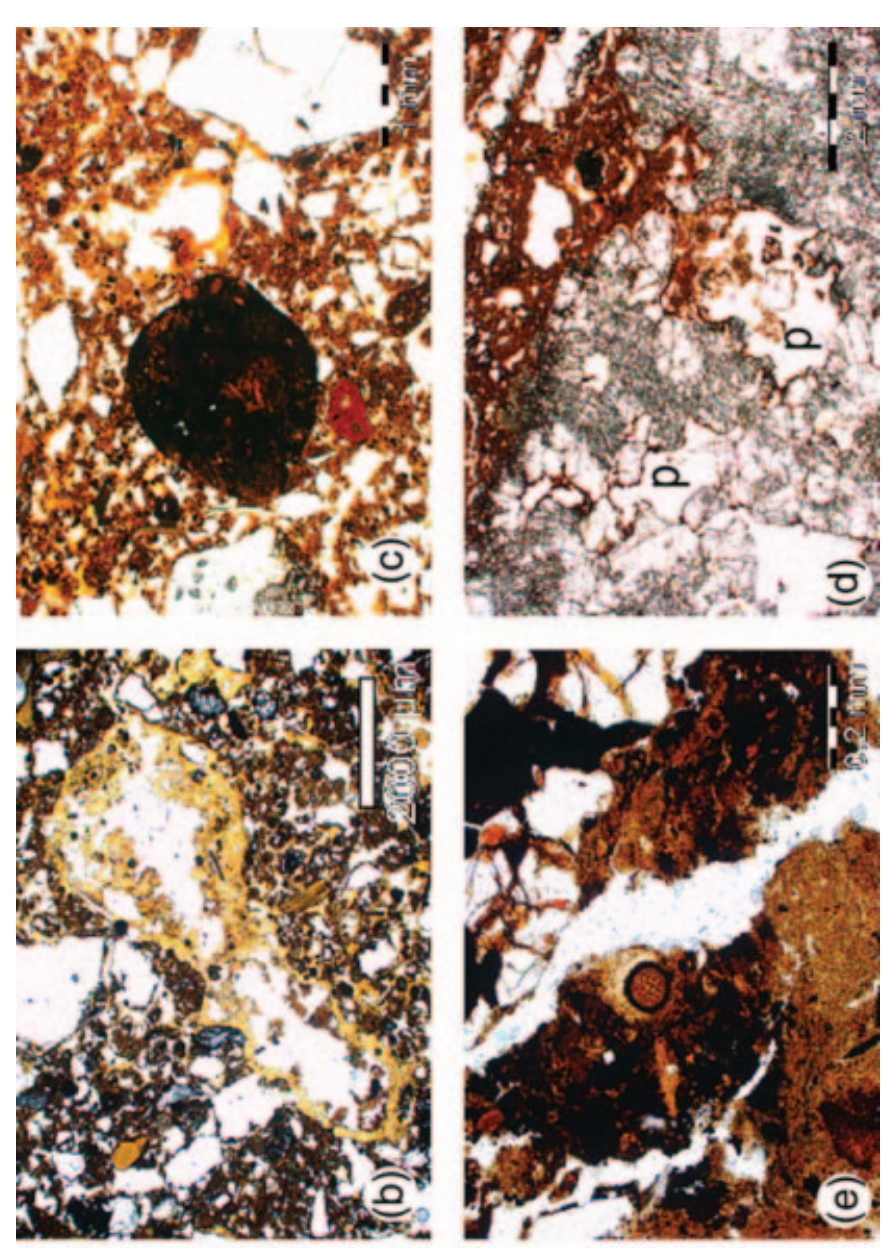

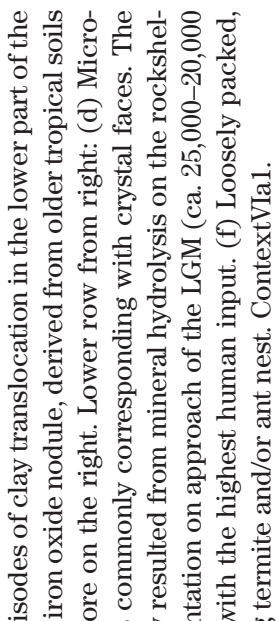

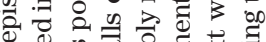

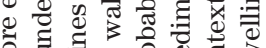

ఏ

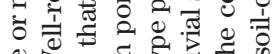

\& $\infty$

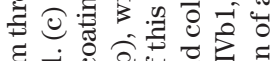

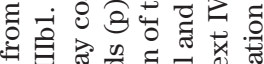

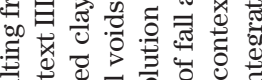

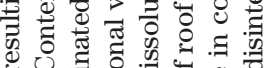

के

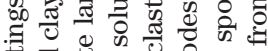

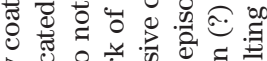

త

उ चै

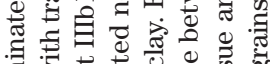
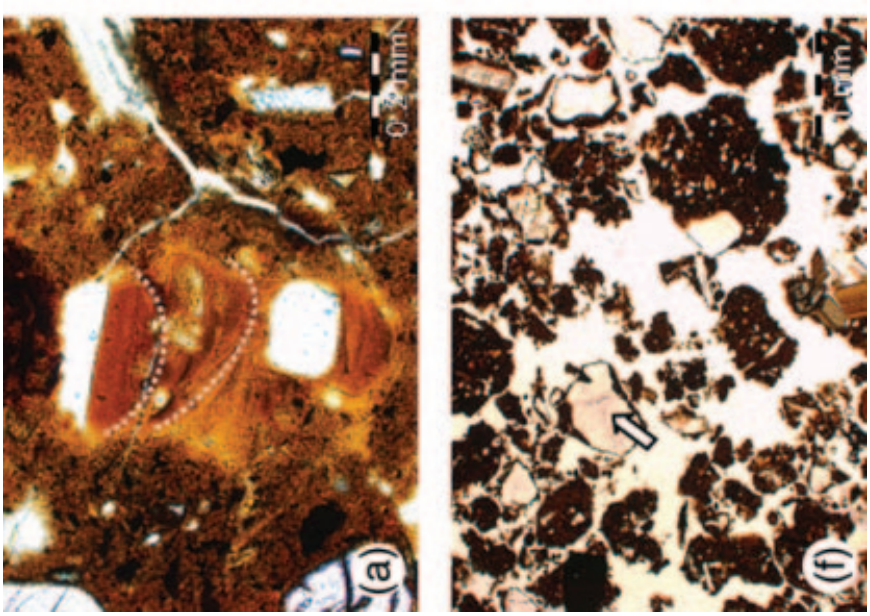

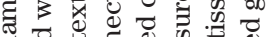

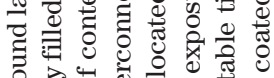

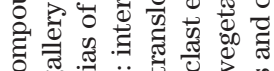

తి

ثี

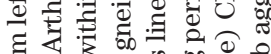

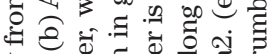

ब

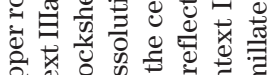

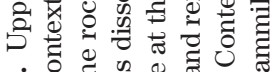

10 0 己

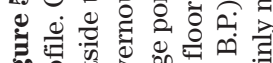

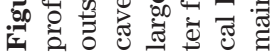


oxide impregnation of the pedoclast micromass ranges from mottling to thorough rubifaction. Although difficult to distinguish from intraclastic ("dysorthic") aggregates derived from in situ reworking of the sediment, it is possible that some of these pedoclasts were derived from the reworking of oxisols/ultisols ("red yellow podzols") that form the characteristic soil type of the region (Deraniyagala, 1992).

The presence of diverse allogenic pedoclasts testifies to the dominant role of colluvial processes sensu lato in the deposition of coarse mineral material in Beli-lena, as documented previously in other rockshelters in the humid tropics (Gillieson, Oldfield, \& Krawiecki, 1986). In view of the common presence of ochre lumps and ochre-stained grindstones among Beli-lena artifacts (Wijeyapala, 1997), it is possible that a fraction of ferricrete fragments were introduced to the rockshelter by humans as ochre.

Figure 3 shows the cross-profile variation of total coarse mineral content and the relative contribution of allogenic particles to the mineral fraction, here expressed as the Allogenic Index $(A I)$ and calculated from point counting results as follows:

$$
A I=(F c+S l) / \Sigma_{\min }
$$

where $F c$ is reworked ferricrete and related clasts, $S l$ is saprolith, and $\Sigma_{\text {min }}$ represents the total coarse mineral content.

Total coarse mineral content fluctuated widely during deposition of the early part of phase III (contexts IIIa2 to IIIb1: ca. 30,000-21,000 cal B.P.). Coarse mineral content then declined in the later part of phase III (contexts IIIc1 to IIIc3; ca. 21,000-16,000 cal B.P.), in tandem with the overall fining up trend of the sediment. Allogenic input was high during deposition of phase III sediments. The transition from phase III to phase IV, depicted as a sharp depositional boundary in the profile, was marked by a sharp increase in coarse mineral content and a decline in allogenic input, evident in clast-supported breccia of context IVb2 and pebbly loams of context Va1. This time of transition, dated at ca. 15,700 cal B.P. and also marked by an abrupt increase in charcoal and other human input (Figure 3), appears to correspond to a period of abrupt change in the depositional system introducing sediment to the rockshelter floor. Clay papule and readily identifiable intraclasts are present rarely across the profile, especially near sharp, erosive surfaces (Table I). The fine mineral content $(<50 \mu \mathrm{m})$ is dominated by quartz and mica silt and variable quantities of as yet unidentified clay minerals.

\section{Human Input: Lithics Processing Refuse and Charred Vegetable Matter}

A notable proportion of the granule- to fine breccia-sized clear quartz content comprises wedge-shaped or platy particles with pointed edges and conchoidal surfaces. Such fragments are interpreted as possible lithics processing refuse (Figure 4d). Notwithstanding uncertainties in its identification in thin section, lithics processing refuse was noted in most contexts. This is consistent with large quantities of clear quartz debitage in the excavated lithics assemblage (Deraniyagala, 1992; Wijeypala, 1997; Table I, Figure 3). 
Wood charcoal and other carbonized plant tissue, including as yet unidentified seeds, parenchyma, and rare fern spores, are present throughout the profile at low frequencies, distributed evenly in the micromass (Figures 4e, 5e). This type of charcoal content probably resulted from reworking of combustion features at some distance from the sampled square and their re-deposition by floor processes, perhaps including faunal activity. It is difficult to infer whether microscopic charcoal and plant tissue was sourced from within or outside the rockshelter on micromorphological evidence alone. The presence of meter-sized hearths (Deraniyagala, 1992; Wijeyapala, 1997) and abundant carbonized vegetable macroremains (Kajale, 1989) throughout the stratigraphy, nevertheless, make the former inference more likely (cf. Hansen, 2001). In a similar vein, silt-sized charred vegetable debris, present throughout the profile at variable frequency, possibly reflects diminution of vegetable food remains by rockshelter floor processes, including arthropod fauna (as discussed later).

The conspicuous depositional boundary that separates phase III sediments from overlying phases demarcates a dramatic change in the frequency of charred organic fragments. Low to very low frequency ( $<2$ to $2-5 \%$ ) in contexts III contrasts sharply with frequencies over $20 \%$ in contexts IV, V, and VI (Figure 3). In these upper contexts, dense accumulations of charcoal and carbonized vegetable material, of size ranging from granule to silt, are associated with rubified and peripherally blackened aggregates. In common with the rest of the sampled profile, these charcoal-rich facies are devoid of ash. These facies are, therefore, interpreted as resulting from reworking of adjacent hearths by runoff, trampling, dissolution of ash $\mathrm{CaCO}_{3}$, bioturbation, and other rockshelter floor processes (cf. Karkanas et al., 2002; Sergant, Crombé, \& Perdaen, 2006). Phytoliths occur very rarely, both within contexts III and higher up, where they are associated with clusters of charcoal. Bone is almost totally absent, with the exception of very rare, sand-sized angular fragments of apparently unburned bone in the upper, charcoal-rich contexts (IV and V). Absence of microscopic bone fragments contrasts sharply with the abundance of larger bone finds on site (Deraniyagala, 1992; Wijeyapala, 1997; Perera, in press), and also with the abundance of microscopic bone fragments from the Late Pleistocene rockshelter site of Batadomba-lena, about $25 \mathrm{~km}$ to the southeast (Kourampas et al., 2008; Figure 1a).

\section{Micromass}

Three types of micromass are present in the lower, poorly aggregated parts of the profile (contexts III):

- $\quad$ reddish silty clay with silt-sized quartz, mica, and opaque particles (charred vegetable debris and/or opaque minerals) and common to pervasive iron oxide mottling (e.g., IIIa3);

- yellow silty clay with low quartz and mica content and pervasive iron oxide mottling (e.g., IIIc2, IIIc3);

- buff-gray to black, isotropic silt with spongy microstructure and frequent charred organic debris. This type of micromass forms patches to 1-2-cm-thick layers within context IIIc1. We interpret these isotropic patches as fecal in origin (Figure 4a). 
In the upper parts of the sampled profile (phases IV, V, and VI), micromass is aggregated and rich in charred vegetable debris.

\section{Pedofeatures}

Iron oxide impregnation pedofeatures, with sharp- and diffuse-boundary nodules, hypocoatings, and 10s-of- $\mu \mathrm{m}$-sized mottles within micromass and clay coatings and fillings (Figures 4b, 4e, 5a, 5d), are present throughout the profile. These are especially abundant in phase III (Table II, Figure 3).

Translocated clay fillings with laminated, organics-rich, silty, and, more rarely, limpid clay, are the most conspicuous pedofeatures of phase III sediments (Figures 3, 5a, 5d). Clay fillings reduce-and in lower contexts occlude-packing and biogenic porosity (e.g., arthropod galleries in IIIb1; Figure 5b). Compound fillings with up to three generations of clay deposits are recognized in the lower parts of phase III (e.g., Figure 5a). Clay fillings are commonly disrupted, with convolute, out-ofphase lamination, fractures, and mosaic extinction patterns. These and related features (e.g., well-developed porostriation on the walls of pores that accommodate clay coatings) evidence wet/dry climatic cyclicity during period(s) of coating translocation. The temporal scale of these cycles remains unresolved.

Isotropic textural and crystalline pedofeatures, possibly of high phosphorus content, are present at very low frequency within phase III samples (Figure 3, Table II). These include gray to black, isotropic coatings on undersides of mineral grains; isotropic typic nodules within the upper part of IIIc1, associated with isotropic buff gray micromass; clear microcrystalline pendents (microstalactites), present very rarely on the undersides of mineral grains; and clear, microcrystalline coatings on fissure/vugh walls. The former two types are present exclusively within the upper part of IIIc; the latter type is present very rarely in the lower parts of IIIc1 and IIIa3. Isotropic typic aggregates are present in higher contexts (IVb2, Va1). These may have resulted from phosphatization or Fe-oxide impregnation of the micromass.

Bioturbation is present throughout the profile with networks of interconnected channels and chambers ("biological porosity," sensu Courty, Goldberg, \& Macphail, 1989). Smooth-walled channels in the lower parts of the profile are filled with translocated clay (Figure 5). The largest channels, most conspicuous in finer-grained facies (e.g., IIIc3; see Figure 4b), were probably made by burrowing arthropods that commonly dominate the floor community of tropical caves and rockshelters (Gillieson, 1996). The intensity of bioturbation is unequal across the profile: The most intensely bioturbated facies is the charred organics-rich sediment of context IVb1 (Tables I, II). Faunal activity is also indicated by frequent fecal pellets of sizes ranging from 50 to $70 \mu \mathrm{m}$.

\section{Microstratigraphy of Kitulgala Beli-lena Deposits}

The stratigraphic boundary across the middle of the profile (Figure 3) has a clear expression at the microscopic level: It divides the profile into an orange to brown, nonaggregated, translocated clay-rich lower part with sporadic human input (contexts 
IIIa, b, c), and a brown, coarser-grained, more closely packed, aggregated upper part, devoid of translocated clay and rich in human input (phases IV, V, VI). Within the lower part of the profile a further subdivision is evident, between coarse-grained diamictic loams to breccia in the lower and middle contexts (up to IIIc1) and finergrained, pebbly silty clays with a marked fining-up trend in the upper contexts (IIIc2 and IIIc3; see Figures 3, 4a, 4b).

Lower Part of Phase III (Contexts IIIa2, IIIa3, IIIb1, IIIc1): Orange/Brown Diamictic Loams/ Breccia with Clay-Filled Biological Porosity-Colluviation, Roof Fall, and Formation of Paleofloors

Heterogeneous microfacies of the lower part of phase III comprise poorly sorted orange/brown diamictic loams to breccia, with biological porosity filled with orange silty clay. The coarse mineral fraction includes unweathered gneiss, saprolith, and reworked soil fragments. Human input is sporadic, including lithics processing residue and charcoal (Table I). The most marked post-depositional features are multigenerational clay coatings and fillings and diverse iron oxide impregnation features (Table II, Figure 5).

A proportion of angular, relatively unweathered gneiss/charnockite clasts must have originated as rock fall from the rockshelter roof and walls, while another part may have derived from outside the rockshelter. The relative contribution of these two sediment sources remains unresolved. Increasing frequency of reworked ferricrete and other probable allogenic material up-section reflects an increasing contribution of material fluxes from outside the rockshelter through time (Figures 3, 5c). Poor sorting of interbreccia matrix, poor expression of bedding/lamination, presence of papule, reworked nodules, and intraclasts suggest that sediment deposition was dominated by colluvial processes sensu latto (cf. Courty, Goldberg, \& Macphail, 1989; Goldberg \& Macphail, 2006). The latter probably comprised a combination of gravity mass flow and slope-wash processes that transported sediment from further upslope into the rockshelter, and surface runoff and other processes of sediment redistribution on the rockshelter floor. The dominant role of slope processes in sediment deposition was previously documented at other tropical rockshelter sites (e.g., in Papua New Guinea: Gillieson, Oldfield, \& Krawiecki, 1986). No evidence for deposition by channel flow was found. It is possible, however, that diagnostic depositional structures were obliterated by bioturbation. Deposition of these sediments was discontinuous through time, as evidenced by the presence of sharp intercontext surfaces at macroscopic level and finer-grained, pebbly silt/clay intercalations within breccia deposits at microscopic level. A proportion of the finer-grained matrix of these poorly sorted facies possibly originated from saprolith (e.g., kaolinite from alteration of feldspars and other minerals) and/or tropical soil cover, infiltrated by water seepage through the joint network of overlying bedrock. Very similar processes of infiltration of fines are well documented at karstic rockshelters (e.g., Gillieson, 1996; Woodward, 1997a, 1997b; Woodward \& Bailey, 2000).

Pebbly loams of contexts IIIa2 and IIIc1 contain sharp surfaces of undulating microrelief draped by up to $1000-\mu$ m-thick microlaminated silty clay (Figure $4 \mathrm{a}$ ). 
These surfaces are interpreted as paleofloors, corresponding to depositional hiatuses of unknown duration (cf. Courty, 2001). Silty clay laminae upon the latter represent very low-energy deposits, possibly infiltrated by water seepage.

Cyclic patterns of accumulation of these heterogeneous facies are interpreted as resulting from episodes of intensified roof fall (breccia) and colluviation that punctuated background deposition by water seepage and slope wash (silty clay). Deposition rates were highly variable. Intense weathering of bedrock clasts, with formation of labyrinthine microcaverns, is consistent with long exposure to aggressive fluids on the rockshelter floor (Figure $5 \mathrm{~d}$ ). The presence of these features suggests that short-lived depositional events punctuated longer periods of minimal deposition and clast weathering. Although their geochemical context of ferrallitic weathering is distinct, these solutional phenomena are analogous to karstic dissolution of roof fall breccia in limestone caves and rockshelters (e.g., Courty, 1986).

Loam/breccia with an isotropic-probably phosphatic-matrix within context IIIc1 is also interpreted as a rockshelter paleofloor (Figure 4a). The buff-brown, isotropic matrix is similar to identifiable coprolithic material in Late Pleistocene deposits from Batadomba-lena rockhelter (Figure 1b). Although no diagnostic content was observed, high charred vegetable silt content possibly suggests broadly contemporaneous human activity. Quite tentatively, therefore, we favor an interpretation of this material as reworked human rather than animal (e.g., bat) excrement. Since excrement is very susceptible to dissolution in the acidic conditions generated by decomposition of its organic content (as reported for bat guano by ShahackGross et al., 2004), it is possible that the ca. 1-2 cm of this microfacies represents the vestiges of thicker original accumulations. Alternative sources of phosphates in this material could be dissolved bone (as discussed below).

Post-depositional bioturbation was relatively moderate, as evidenced by the survival of primary sedimentary structures. Channel dimensions and morphology are consistent with descriptions of soil-dwelling termite galleries in the literature (Jungerius, van der Anker, \& Mücher, 1999; Cosarinski \& Roces, 2007). Filling of inferred termite channels with clay (Figure 4b) took place at later times, in conjunction with the deposition of overlying clayey sediment and/or translocation of clay across the profile.

The lower part of phase III is, therefore, interpreted as an admixture of roof fall and colluvial deposits, reworked by surface runoff, trampling, and other floor processes and subjected to post-depositional bioturbation, possibly by termites.

\section{Upper Part of Phase III (Contexts IIIc2 and IIIc3): Fining-Up Orange Pebbly Clay_Slow Deposition by Water Seepage and Colluviation}

This part of the stratigraphy comprises clayey sediments with decreasing coarse mineral content up-section, high allogenic content, and relative paucity of roof fall debris (Table I, Figures 3, 4b). This facies probably reflects reduced rates of roof and wall disintegration and predominance of water seepage and slope wash processes. Much of the clayey matrix was possibly infiltrated through the joint network from overlying saprolith and soils. Colluviation contributed allogenic clasts and, probably, a proportion of bedrock clasts and fines. A marked decrease in coarse 
mineral content up-section (Figure 3) suggests that roof fall rates diminished through time during the ca. 6000 years represented by this part of the stratigraphy. Reduced sedimentation rates are indicated by the reduced thickness of the deposits and the highly weathered state of many bedrock clasts, possibly reflecting long periods of exposure on the rockshelter floor. Rockshelter floor runoff probably redistributed fines and, possibly, some of the coarser mineral content. The presence of charred organic silt in the fines suggests that combustion-related human activity took place in the rockshelter, possibly located more distally and closer to the entrance. Translocated clay in biogenic pores resulted from drainage by percolating water. Iron oxide impregnation suggests that these sediments were subjected to postdepositional wetting and drying. Bioturbation was extensive and multiperiod, locally resulting in almost complete homogenization of the sediment. A first generation of bioturbation, indicated by multiconcave vughs, was probably followed by a period of sediment waterlogging and pore collapse (cf. Courty, Goldberg, \& Macphail, 1989). Cm-scale channels and burrows (Figure 4b) were excavated later by unidentified arthropods. Connection of single burrows with smooth-walled, oval chambers seems to suggest some kind of nesting structure, possibly made for egg deposition. The absence of clay coatings, sediment fill, and iron oxide hypocoatings from these burrows may indicate a relatively recent age.

\section{Phase IV (Context IVb1): Charcoal-Rich, Clast-Supported Breccia-Accelerated Roof and Wall Disintegration, Colluviation, and Human Activity}

This context comprises orange brown, clast-supported breccia, with angular, mainly unaltered bedrock clasts within a matrix of coarse sand to granules. The matrix microstructure is granular, with rubified and blackened aggregates in association with charred vegetable remains, including possible fern spores (Figure 5). Compared with underlying deposits, context IVb1 yields a markedly stronger cultural signal, with frequent lithics processing residue and the highest wood charcoal and other charred vegetable tissue content in the entire sampled profile (5-15\%; Table I, Figures 3, 5e). High quantities of predominantly angular, unweathered coarse mineral debris were probably derived from roof and wall disintegration. It is possible that use of fire by humans contributed to wall disintegration by producing a thermoclastic effect (differential expansion and contraction of minerals) on the coarsecrystalline, highly heterogeneous gneiss bedrock. Colluvial activity continued during this short period (possibly as short as ca. 1000 years in view of the current dating evidence; Figure 3), but its relative contribution was reduced in comparison with the preceding period. Human presence in the rockshelter also contributed tool-making refuse, food remains, and a diverse array of combustion by-products. Peripheral blackening of well-rounded aggregates associated with charcoal evidently suggests that aggregation preceded, or resulted from, combustion. Distinct charcoal accumulations in laminae/lenses (Figure 4c) probably resulted from reworking by rockshelter floor processes (e.g., surface runoff, trampling, etc.). In contrast with reports of ash accumulation and in situ hearths (Wijeyapala, 1997), ash is absent from thin sections of this context. This may reflect distance of the sample from the original 
hearths or post-depositional dissolution of ash $\mathrm{CaCO}_{3}$, in analogy with similar reports from European caves and open air sites (Karkanas et al., 2002; Sergant, Combé, \& Perdaen, 2006). Biological activity on the soil zone above the rockshelter and/or the rockshelter floor, receiving human habitation debris, may have lowered the $\mathrm{pH}$ of percolating water, thus promoting ash dissolution. Human habitation debris may have also attracted floor fauna, resulting in intense bioturbation and aggregation of the sediment (Tables I, II). Overall, this facies reflects increased energy of the depositional system, with a synergy between accelerated water seepage, high rates of colluviation, and diverse human activity, resulting in accelerated sedimentation in the millennium following ca. 15,700 cal B.P.

\section{Phase V (Context Va1): Charcoal-Rich Pebbly Loam-Seasonal Colluviation, Roof Fall, and Human Activity}

Similar overall to the underlying context, this brown, poorly sorted loam, with angular clasts, charcoal, and lithics processing residue and weakly discernible, mmscale lamination, is richer in fines (Table I, Figure 4d). This context appears to contain the most diverse charred vegetable content, with wood charcoal, charred soft tissue, and at least one charred seed fragment. Roof fall supplied much of the coarser mineral content of these sediments, whereas coarse colluvial input from external sources was reduced markedly (Figure 3). Finer-grained sediment was supplied by water seepage and colluvial processes as in the underlying context. Sharp laminaebounding surfaces, erosional contacts, and intraclasts within finer-grained intercalations suggest that surface water flow on the rockshelter floor was seasonal, eroding previously deposited dry sediment. Laminar and lenticular intercalations of charcoal probably resulted from redistribution of charred particles by seasonal surface runoff washing over hearths or hearth debris in the vicinity. Human activity contributed combustion, food, and tool-making refuse that form a considerable proportion of the sediment. Trampling is indicated by the compaction of clayey interlaminae, the tapering shape of clayey intraclasts, and, possibly, by subvertical, pointed end-down position of many microliths and tool processing residue (Figure 4d) (cf. Gifford-Gonzalez et al., 1985). Evidence for bioturbation by cave floor fauna (possibly termites and/or ants) is also high in this sediment. Overall, this context represents deposition by roof fall, colluviation, and human activity under a seasonally wet climate from ca. 14,850 to 13,800 cal B.P.

\section{Phase VI (Context VIa1): Aggregated Loam-Disintegration of Termite and/or Ant Nest}

This context includes aggregated, loosely packed, brown pebbly sandy loam with mammillate, porous, mainly equidimensional, clayey aggregates; few well-sorted, coated mineral grains; and the only unequivocal bone fragments in the sampled profile (Table I, Figure 5f). Coarse mineral content is the lowest in the sampled profile (7-15\%; Table I, Figure 3). This fully aggregated sediment probably resulted from disintegration of a soil-dwelling termite and/or ant nest. A number of critical textural and structural features (e.g., good sorting of sand-sized grains, predominance 
of fines, pervasive aggregation and grain coating, and mammillate to serrate shape of aggregates; see Figure 5f) suggest that this facies represents bioconstruction by social insects. Both termites and ants select grains of uniform size, generally $<1300 \mu \mathrm{m}$, and incorporate them with fines in composite, mammillate aggregates which they then move upward along the gallery network to use as building material for the construction and maintenance of the nest (McBrearty, 1990; Jungerius, van der Anker, \& Mücher, 1999; Cosarinski \& Roces, 2007). The loose, crumb to granular microstructure of this sediment is remarkably similar to the single report of termite mound colluvium in the literature (Jungerius, van der Anker, \& Mücher, 1999). High frequency of coated grains also points toward involvement of termites in the production of this facies (Cosarinski \& Roces, 2007). Plausible perpetrators include species of Ceylonetermes or ecologically similar mound-building, soil-dwelling termite genera of the South and Southeast Asian rainforests (Collins, 1989). At the same time, it should be emphasized that mounds and subterranean galleries also attract arthropod fauna other than their original makers (Collins, 1989; Dejean, Bolton, \& Durand, 1997) and that ants are known to modify and use termite mounds (Cosarinski \& Roces, 2007).

\section{DISCUSSION}

Late Pleistocene to Early Holocene archaeological deposits in Beli-lena reflect a complex interplay between interdependent climatic, ecological, geomorphic processes, and human activity, which brought together components from disparate sources from within and outside the rockshelter. Unraveling the relative contribution of these processes to the formation of a rockshelter's sediment record is a challenging task. In the case of Beli-lena, the challenge is exacerbated by the paucity of published micromorphological accounts of cave and rockshelter sediments from the humid tropics (Stephens et al., 2005; Lewis, 2007) and the virtual absence of such accounts from directly comparable non-karstic settings. Our interpretation of the site is, thus, quite inevitably, provisional. In this section we discuss our assessment of the relative contribution of processes of sediment deposition and postdepositional change to the formation of Beli-lena's sediment record, and articulate a working hypothesis linking on-site processes with landscape-scale Late Quaternary environmental change.

\section{Late Pleistocene to Early Holocene Sediment Deposition and Post-Depositional Change in Beli-lena}

Our current understanding of the range of depositional processes operating in Beli-lena (and similar rockshelters on the slopes of noncarbonate bedrock in the humid tropics) is described schematically in Figure 6. Many of these processes (e.g., roof fall, colluviation, infiltration of fines) are identical to those described previously from karstic rockshelters and the near-entrance zone of caves in temperate settings (e.g., Gillieson, 1996; Woodward \& Bailey, 2000; Courty \& Vallverdú, 2001; Woodward \& Golberg, 2001). Gneiss bedrock lithology, high annual rainfall, the 


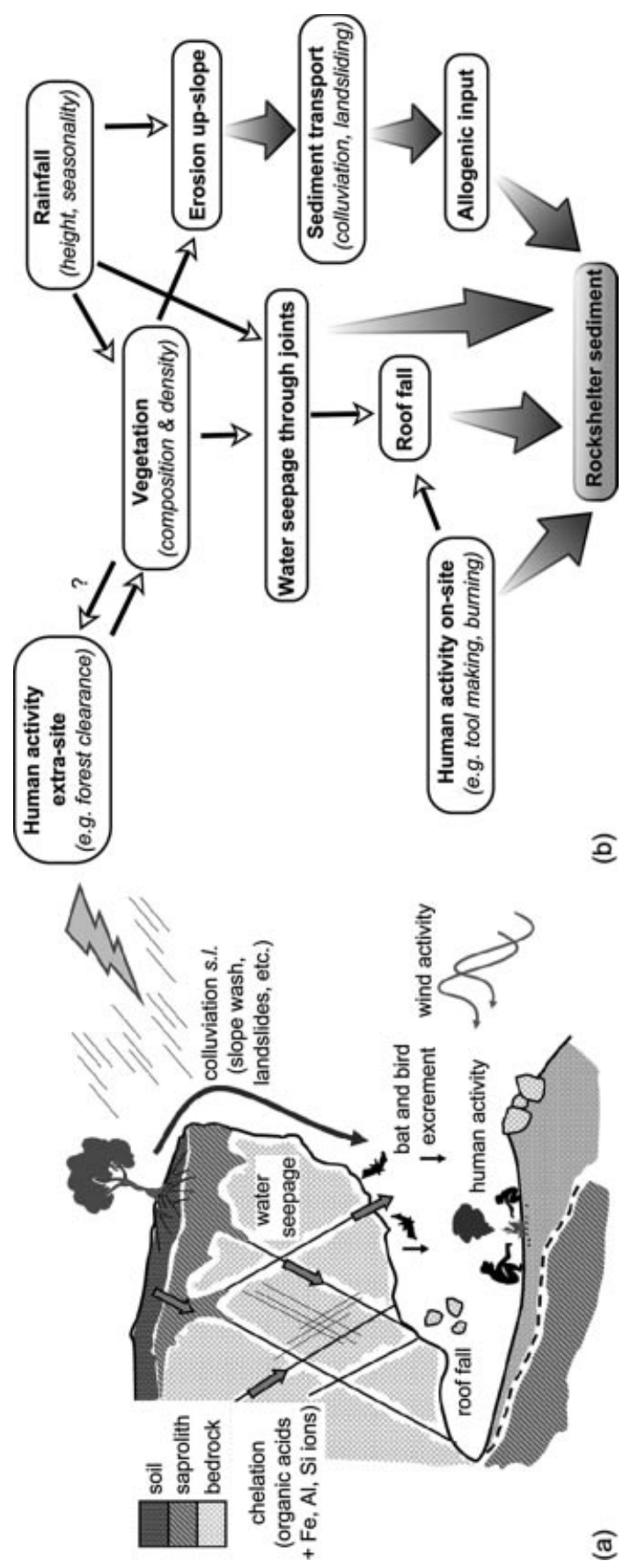

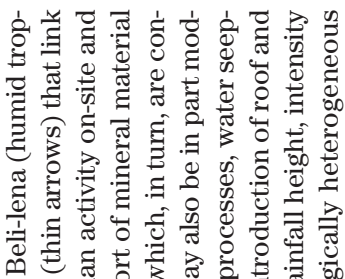

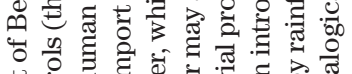

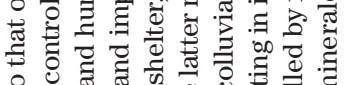

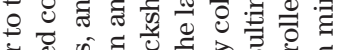

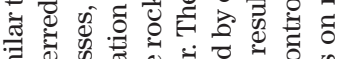

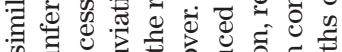
क力

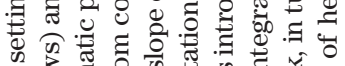

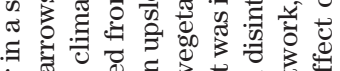

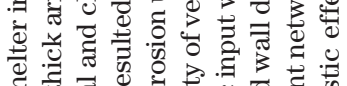

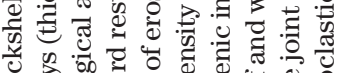
\%

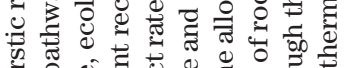

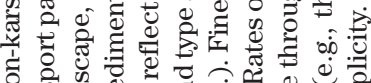
O đ్

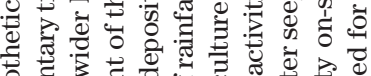

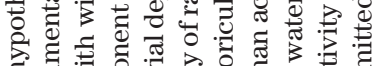

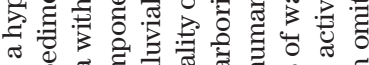
ङ

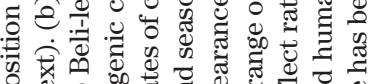

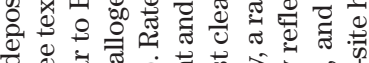

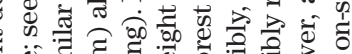

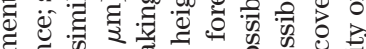
娄

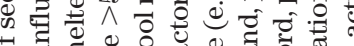
需界 क 纯

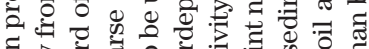

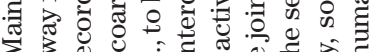

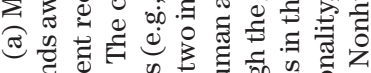
๑

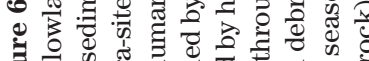

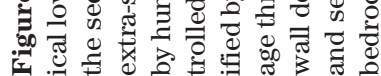


distinctive biogeochemical processes of ferrallitic weathering (Birkeland, 1984; Thomas, 1994), and the complex effects of rainforest vegetation on slope stability (Greenway, 1987), however, mark the geomorphic context of Beli-lena (and similar tropical rockshelters) as distinct.

Situated ca. $60 \mathrm{~m}$ above present stream level, Beli-lena was probably outside the zone of fluvial activity during most of the ca. 25,000 years spanned by the sampled part of the stratigraphy. In any case, with the possible exception of imbricated pebbles at the (non-sampled) base of the profile ( $>31,000$ cal B.P.), no unequivocal evidence for fluvial deposition was noted. Field evidence, macroscopic facies (Wijeyapala, 1997), and the present microstratigraphic analysis suggest that the main processes transporting sediment in the rockshelter included (Figure 6):

- Colluvial processes sensu lato, including slope wash, mass movement, and surface wash on the proximal ramp of the rockshelter. Colluvial processes have been identified as major contributors of sediment in both temperate and tropical rockshelters (Butzer, 1981; Gillieson, Oldfield, \& Krawiecki, 1986). Mass movement, in the form of basin-wide landslides and debris flows, in particular, is a very important sedimentary process in humid southwestern Sri Lanka (Gunatilaka, 2007). Its contribution may have been even greater in Pleistocene times, accounting for the formation of placer gem deposits (Gunatilaka \& Almond, 2001; Gunatilaka, 2007);

- Water seepage through the joint network, which, in addition to introducing fine sediment from the overlying soil and saprolith, may have contributed $\mathrm{Fe}, \mathrm{Al}$, and $\mathrm{Si}$ ions, brought in as chelates (soluble organomineral acids) from the biologically active soil zone (Birkeland, 1984; Thomas, 1994);

- Roof and wall disintegration, which occurred intermittently during deposition of the sampled profile;

- Human activity on-site, which contributed sediment in a number of ways, ranging from combustion, food consumption, and excretion, to deliberate introduction of mineral material for tool making or, perhaps, to be used as ochre;

- Presence of bats and birds, which contributed significant quantities of guano after cessation of regular human use in the Holocene (Wijeyapala, 1997) and, possibly, in earlier, as yet unidentified, periods of rockshelter abandonment. Diverse micromammals, termites, and other arthropods bioturbated the sediment diachronically.

Since many of these depositional processes were interdependent, links between them, however difficult to identify conclusively, should be hypothesized (Figure 6b). Human-built fires, for instance, may have facilitated rockfall through a thermoclastic effect on the mineralogically heterogeneous, gneissic bedrock.

As described in the preceding section, episodically deposited rock fall and colluvia with sporadic human input at the base of the profile (contexts IIIa3, IIIb1, IIIc1) were succeeded by clay deposited slowly by water seepage, mixed with externally sourced colluvium (contexts IIIc2, IIIc3). These finer-grained facies correspond with the four to five millennia that bracket the LGM. Higher-energy roof fall and colluvial deposits with high human input associated with combustion activity that come above 
LGM deposits reflect relatively rapid deposition between ca. 15,700 and 14,000 cal B.P. Allogenic input apparently declined during the ca. 2000 years represented by their deposition. The topmost sample represents sediment from the disintegration of a soil-dwelling termite nest. Its structural characteristics, therefore, do not reflect (primary) depositional conditions.

Difficulties in interpretation notwithstanding, sediment deposition pathways shown in Figure 6 provide potential causal links between sediment facies in the rockshelter and processes operating in the dynamic surrounding landscape, as discussed below (cf. Gillieson, 1996; Woodward \& Bailey, 2000; Woodward \& Goldberg, 2001; Goldberg \& Macphail, 2005; Goldberg \& Sherwood, 2006).

\section{Human Use of the Rockshelter}

At the microscopic scale, the principal sediment constituents introduced by human activity include microliths and tool-processing refuse, present throughout the profile, and, probably, charcoal and other charred vegetable matter, which increased dramatically ca. 15,700 cal B.P. (Figure 3). In addition, cm-scale concentration of inferred phosphate-rich clay in the upper parts of context IIIc1 probably marks a ca. 21,000-years-old paleofloor (cf. Courty, 2001). The picture emerging from this investigation is, thus, of a rockshelter used intermittently from ca. 30,000 to ca. 15,700 cal B.P. by hunter-gatherers who made tools and lit fires at or near its entrance. Use of fire and, somewhat less conspicuously, tool making, appear to have intensified around 15,700 cal B.P., possibly reflecting an increased frequency of visitations and/or longer stays by visiting groups. Correlative with increased abundance of animal and vegetable food macroremains (Kajale, 1989; Deraniyagala, 1992; Wijeyapala, 1997), this increase in microscopic human input is interpreted as evidence for intensification of rockshelter use around 15,700 cal B.P. It is noteworthy that evidence for intensified human presence in about the same period (16,000-14,000 cal B.P.) is present at the Batadomba-lena rockshelter within the same ecological zone (Figure 1b). This invites the hypothesis that intensification of rockshelter use during that time was a regional development among hunter-gatherer societies in inland southwestern Sri Lanka (Kourampas et al., 2008).

\section{Bioturbation by Termites and Other Arthropods}

Bioturbation by rockshelter floor fauna occurred at more than one phase and scale, as evidenced by the presence of both filled and unfilled channels and chambers of variable dimensions. A distinction can be made between moderately bioturbated facies (phase III contexts), characterized by channel and chamber microstructures, and highly bioturbated facies, characterized by crumb and granular microstructure (phases IV, V, and VI). A marked correlation between pronounced sediment aggregation and high anthropogenic content (charcoal, lithics processing refuse) suggests that rockshelter floor fauna were attracted to organic debris from human activity (e.g., food and fuel refuse). A similar concentration of insect bioturbation in anthropogenic microfacies was noted in the adjacent Batadomba-lena rockshelter (Kourampas et al., 2008; Figure 1b). 
Identification of the bioturbating agents is difficult in the absence of reference material and the scarcity of micromorphological descriptions of bioturbated sediments and soils in the literature. In any case, tropical rockshelter floors are likely to host complex communities of burrowing arthropods (Gillieson, 1996). Organic input from human activity, in addition, can augment the numbers of detritivores and their predators. Nevertheless, shape, dimensions, and clayey lining/filling of burrows in phase III sediments appear very similar to descriptions of termite galleries in the literature (e.g., Jungerius, van der Anker, \& Mücher, 1999; Cosarinski \& Roces, 2007). The accumulation of clayey-sandy crumb aggregates that constitutes context VIa1 was interpreted as colluvium resulting from disintegration of a termite nest (cf. Jungerius, van der Anker, \& Mücher, 1999). This is not to say that termites were the only insect bioturbators present on-site: Termite nests are niches of diverse soil fauna, hosting a wide range of symbiotes, predators, and successive occupants (Cosarinski \& Roces, 1997; Dejean, Bolton, \& Durand, 1997).

\section{Phosphate Deposition and the Intriguing Absence of Microscopic Bone}

Identification of micromorphological features as phosphates remains provisional and processes of phosphate deposition are inferred only tentatively at this stage. If correctly identified, phosphate re-deposition, in the form of distinctive textural pedofeatures, appears to have been minimal in the sampled section, located mainly underneath the inferred ca. 21,000 cal B.P. paleofloor with inferred excrement accumulation (context IIIb1; see Figure 3). Phosphate-rich pore fillings and coatings, present at very low concentration in the lower part of the profile (Table II, Figure 3), may have also derived part of their phosphorus from fecal material. Additional sources of phosphorus may have included bone and animal protein and, to a lesser extent, diverse vegetable sources (Weiner, Goldberg, \& Bar-Yosef, 1993; Karkanas et al., 1999, 2000, 2002; Karkanas, 2001; Shahack-Gross et al., 2004).

The virtual absence of microscopic bone fragments from the sampled sediments contrasts sharply with the abundance of macroscopic bone finds at the site (Deraniyagala, 1992; Wijeyapala, 1997; Perera, in press). Microscopic bone fragments are also common at the Late Pleistocene rockshelter site of Batadomba-lena, in the same climatic zone (Kourampas et al., 2008; Perera, in press) and the terminal Pleistocene open-air site of Bellan-bandi Palassa, in seasonally arid southern Sri Lanka (Simpson, Kourampas, \& Perera, 2008; Figure 1b). This contrast invites the hypothesis that selective elimination of microscopic bone took place in the burial environment of Kitulgala Beli-lena. Alternatively, microscopic bone fragments may never have been there: Human activity may have only resulted in production of large $(>\mathrm{cm})$ bone fragments. This conundrum may be resolved by analysis of macroscopic bone finds for evidence of post-depositional dissolution and diagenetic alteration.

\section{Clay and Iron Oxide Translocation}

Translocated clay is widespread in the lower part of the section (contexts III) and virtually absent from the upper part of the section (phases IV, V, VI; Table II, Figure 3). More detailed work is required to elucidate the mineral composition of coating 
sequences and infer depositional conditions by reference to experimentally produced clay illuviation features (Dalrymple \& Theocharopoulos, 1984; Theocharopoulos \& Dalrymple, 1987). It is clear, however, that the percolation of vadose water responsible for deposition of clay coatings was episodic. A decrease in the number of identified coating episodes up-section throughout phase III (from up to four in IIIa2 and IIIa3 to two or one in IIIc3) possibly suggests that clay translocation was a diachronous process. Our current working hypothesis is that clay translocation episodes corresponded with increased drainage of the overlying sediment column by meteorically derived percolating fluids and, thus, with periods of increased rainfall. The usefulness of this micromorphological feature as a climate proxy is, however, limited by the difficulty in establishing its timing in relation to dated depositional units.

Clay translocation across the sampled profile took place in a chemical environment of ferrallitic weathering, as manifested by the presence of iron oxide hypocoatings within clay coatings and fillings and the abundance of iron oxidation spots and incipient nodules throughout the profile-especially within contexts IIIc2 and IIIc3. Fluids percolating through phase III were charged with ions probably derived from mineral hydrolysis in the rockshelter wall, overlying sediment, and, possibly, more distal sources (e.g., the overlying soil zone; see Figure 6). Iron oxide mobilization is greatly enhanced by the presence of organic acids which transport iron ions in soluble chelate organomineral compounds. The latter were generated by the input of humic acids derived from decomposition of organic matter in the rockshelter and, probably, in the soil mantle above (Birkeland, 1984; Thomas, 1994). Since the rockshelter floor was probably situated well above the local water table throughout the last ca. 30,000 years, the abundance of iron impregnation features is thought to reflect intermittent waterlogging of the sediment (Bullock et al., 1985; Courty, Goldberg, \& Macphail, 1989). Watterlogging may have occurred seasonally or for more extended periods, perhaps at the bottom of slack-water pools. In the monsoonal context of the site, waterlogging may have resulted from pronounced rainy seasons. The significance of iron oxide pedofeatures as paleoclimatic proxies is, however, limited by the difficulty in dating them. Although these features may reflect a Late Pleistocene climate, it is also possible that some resulted from monsoonal conditions in the Holocene.

Clay translocation and iron impregnation features confer to the lower, older than 15,700 cal B.P., part of the profile the micromorphological characters of an incipient tropical ultisol. Comparable evidence for advanced pedogenesis was found by Mercader et al. (2003) in non-karstic rockshelter deposits of Holocene age in the Ituri rainforest, Congo. It should be noted, however, that, in Beli-lena, pore-filling clay may be partly sedimentary in origin, that is, contemporaneous with deposition of overlying clayey sediment (e.g., the clayey contexts IIIc2 and IIIc3; see Figure 3) and, thus, not simply a product of advanced pedogenesis.

\section{Possibility of Post-depositional Mineral Hydrolysis}

The presence of highly porous clasts, with voids occupying up to 50\% of grain surface, in the lower parts of the section (e.g., IIIb1) raises the possibility that hydrolysis of silicate minerals (e.g., pyroxenes, amphiboles, feldspars) continued after 
clast deposition on the rockshelter floor. Some of these clasts are marked by irregular microcavernous pore networks (Figure 5d); others are little more than a boxwork of empty, striated coatings that line molds of completely dissolved crystals. Such moldic-porous grains are present in breccia and pebbly loams of phase III, interpreted as roof fall and colluvia deposited at the onset of, and during, the LGM. In their present state, these porous lattices of clay appear too fragile to have survived transport and deposition in the relatively high-energy conditions inferred from their sedimentary context. A plausible explanation for their occurrence is that mineral hydrolysis took place in situ, after deposition of clasts on the rockshelter floor and, probably, before burial by a fine-grained matrix. Analogous processes of solutional alteration of carbonate clasts on the floor of karstic caves and rockshelters in Europe are described by Courty (1986). If corroborated by further evidence, these features would suggest that conditions of active ferrallitic weathering; that is, broadly humid tropical climate with high annual rainfall and mean annual temperature, were present at least seasonally during deposition of the lower part of phase III, in the millennia leading to, and including, the LGM. Clast weathering would probably be favored by long exposure on the rockshelter floor. This feature, in consequence, is a further indication of episodic deposition of phase III, with long periods of little deposition and clast erosion punctuated with shorter periods of roof fall and colluvial flux.

\section{Linking Beli-lena with the Surrounding Landscape: Late Pleistocene Weakening and Recovery of the Southwestern Monsoon}

A principal objective of this study is to evaluate whether signals of Late Quaternary environmental change can be inferred from clastic sediments in non-karstic rockshelters in southwestern Sri Lanka. The Late Quaternary of the monsoonal tropics was characterized by cyclical variations in temperature and rainfall, driven by millennial to centenary changes in the intensity of the Southwestern (summer) Monsoon. Monsoonal cyclicity was coincident with glacial/interglacial cyclicity in higher latitudes. Late Quaternary change in monsoonal activity is thought to reflect orbital forcing of the global climate (Stott et al., 2002; Ivanochko et al., 2005). Abrupt shifts in the intensity of monsoonal circulation are also correlated with Heinrich Events, reflecting episodic release of glacial meltwater in the North Atlantic (Wang et al., 2001). Recent analyses of various terrestrial and marine high-resolution climatic proxies (pollen records, lake levels, offshore sediments, speleothems, bat guano) suggest that monsoonal activity in the tropics was reduced considerably during the LGM and that post-LGM resumption of monsoonal circulation was probably an abrupt, episodic process (Wang et al., 2001; Gupta, Anderson, \& Overpeck, 2003; Ivanochko et al., 2005; Bird et al. 2007; Lachniet, 2009). Late Pleistocene vegetation in the tropics followed the climatic cue, with widespread retreat and/or taxonomic reorganization of rainforests in many parts of the low-latitude world during the colder and drier LGM, followed by rainforest expansion and renewed taxonomic reorganization in post-LGM times (Jackson \& Overpeck, 2000; Bird et al., 2005; Anhuf et al., 2006; Hunt, Gilbertson, \& Rushworth, 2007). 
Consistent with this regional pattern, cycles of vegetation change during the last 24,000 years in the highlands of Sri Lanka were linked to the changing intensity of the Southwestern Monsoon. Based on palynological and isotopic proxies, Premathilake and Risberg (2003) documented grassland expansion at the expense of montane rainforest resulting from cessation of the Southwestern Monsoon during the LGM, reexpansion of montane rainforest with reestablishment of the Southwestern Monsoon after the end of the LGM, and millennial-scale shifts in vegetation cover reflecting Holocene variation in monsoonal activity. Is it possible to infer potentially correlative, millennial-scale climatic signals from rockshelter sediments in the archaeologically crucial wet lowland ecozone?

Interpretation of rockshelter sediments as proxies for regional processes is often faced with the challenge of assessing the relative contribution of processes that transport sediment from outside the rockshelter, thus providing causal links between the site and the wider landscape (e.g., fluvial activity, water seepage, slope wash, mass movement, mobilization of ions in solution, as in karstic and ferrallitic weathering processes, etc.), and processes that reflect sediment production and deposition on-site (e.g., roof and wall disintegration, biological activity on-site, etc.; see Woodward \& Bailey, 2000; Woodward \& Goldberg, 2001; Figure 6a). Practically, this is translated in the challenge of distinguishing between allogenic and authigenic (originating on-site) sediment content, a question of sediment provenance.

Pathways of material transport to a rockshelter differ from site to site, depending on ecological and geomorphic setting and hydrologic regime. In consequence, responsiveness of rockshelter sediment records to regional environmental change is variable and location-specific (Woodward \& Goldberg, 2001). Human activity can contribute allogenic mineral components intentionally, thus reflecting cultural specificity (e.g., quartz or flint for tool making, iron oxides to be used as ochre), or inadvertently (e.g., sediment brought in on human shoes and clothes, animal hides, etc.). At the same time, human activity can enhance in situ roof and wall disintegration (through, for instance, thermoclastic effects of hearth fires on the rockshelter walls and roof, as suspected for Beli-lena, or by the rubbing of human bodies on friable walls of narrow rockshelters, as suggested for Australian sites; Ward et al., 2006). Since it is often impossible to disentangle human input from that of (other) sedimentary processes (Courty, Goldberg, \& Macphail, 1989; Woodward \& Bailey, 2000; Woodward \& Goldberg, 2001; Woodward \& Morley, 2008), human activity can complicate the identification of sediment provenance at a rockshelter site.

These difficulties are, of course, present at Beli-lena, exacerbated by the relative paucity of sedimentological and micromorphological research in comparable rockshelters in the humid tropics that could guide our interpretations. In some ways, however, Beli-lena is a relatively advantageous site: Human input to a crucial part of its stratigraphy, including the LGM, was only sporadic, geomorphic setting allows inference of at least a number of sediment transport pathways and processes (Figure 6), and a part of the allogenic contribution to the coarse sediment fraction (reworked ferricrete and related pedoclasts) is readily identifiable in thin section (Figures 3, 5c).

Figure 6 is a simplified summary of potential links between the sediment record of a lowland tropical rockshelter in metamorphic bedrock and processes operating over 
the wider landscape. The interrelation of climate change, ecosystem change, and human activity at several levels makes tracing sedimentary effects back to their landscape-scale causes an inherently uncertain exercise. This ambiguity is further exacerbated by the problem of equifinality: the possibility that practically indistinguishable depositional effects may have resulted from more than one cause. These sources of uncertainty notwithstanding, we develop a working hypothesis that links the sediment record in Beli-lena with two dominant external controls over sedimentation on the slopes of m- to km-sized host landforms: rainfall and vegetation cover (Figure 6). Potential causal links are provided by the relative contribution of allogenic colluvial input and markedly episodic roof fall deposits, which, as described, varied significantly during the ca. 23,000 years represented by the sampled profile. The sediment sequence registers a decreasing coarse sediment input during LGM, interspersed with episodic colluvial deposits and roof fall. Allogenic input is high, reflecting high rates of erosion upslope. There is a dramatic change in the dynamics of the sedimentary system in the rockshelter ca. 15,700 cal B.P., marked by an increase of coarse sediment content derived from roof fall. Allogenic input decreases markedly after ca. 15,700 cal B.P., reflecting decreasing rates of erosion upslope of the rockshelter.

The proposed interpretation is shown on Figure 7. Episodic deposition of the lower part of phase III, leading to the LGM, probably reflects increased climate seasonality while monsoonal activity weakened. High allogenic input in this phase reflects high erosion rates upslope of the site, possibly resulting from a vegetation cover adjusting to cooler, drier, and more seasonal LGM conditions. This does not necessarily imply extensive retreat of the rainforest as inferred from other monsoonal regions in South and Southeast Asia (e.g., the environs of Niah Cave in Borneo; Gilbertson et al., 2005; Bird et al., 2005; Hunt, Gilbertson, \& Rushworth, 2007). Alternatively, biome response to LGM conditions may have involved fragmentation of the forest, localized retreat from vulnerable spots of steep topographic gradient (e.g., steep slopes, as occur around Beli-lena; Figures 2, 3), or taxonomic reorganization of the flora, with migration of montane rainforest species to the lowlands (analogous to models proposed for the LGM composition of the western parts of the Amazon rainforest on the foothills of the Andes; Anhuf et al., 2006). Indeed, the distinctly arboreal character of mammalian and snail fauna (Deraniyagala, 1992; Wijeyapala, 1997; Perera, in press) and the presence of rainforest species, such as wild banana (Musa acuminata, M. balbisiana) and breadfruit (Artocarpus nobilis), in the charred vegetable content of Beli-lena sediments (Kajale, 1987) probably suggest that rainforest of currently unknown composition and continuity persevered in the environs of the rockshelter even during the LGM. The upper parts of phase III (contexts IIIc2, IIIc3) comprise slowly deposited, low-energy water seepage sediments with relatively minor roof fall input, probably corresponding to the period of weakest monsoonal activity during the peak of the LGM.

This facies was succeeded by a relatively short period of abrupt change in the dynamics of the sedimentary system in the rockshelter (phase IV, ca. 15,700 cal B.P.). This short-on the order of one millennium on the basis of current chronological evidence-period of accelerated change is interpreted as reflecting abrupt intensification of the Southwestern Monsoon that marked the end of the LGM in the region 


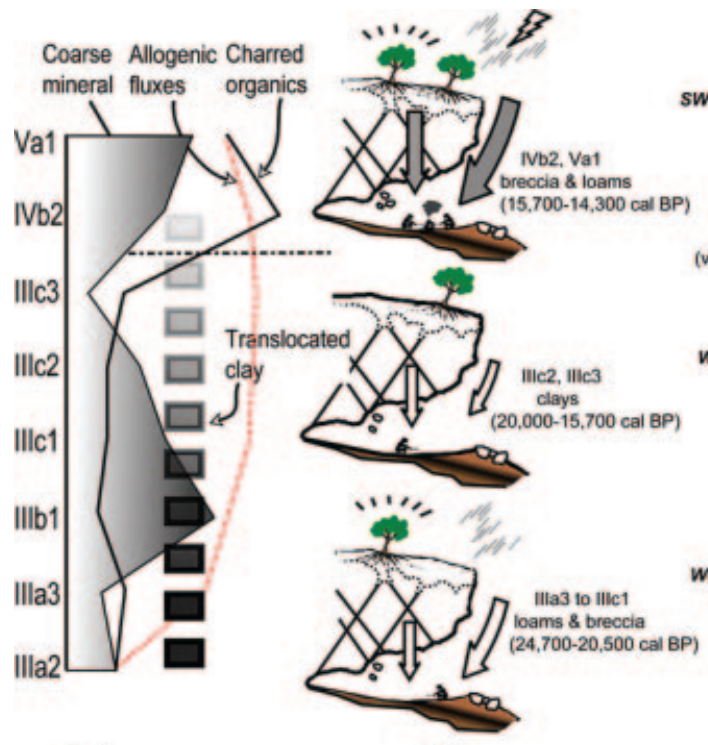

(a)

(b)

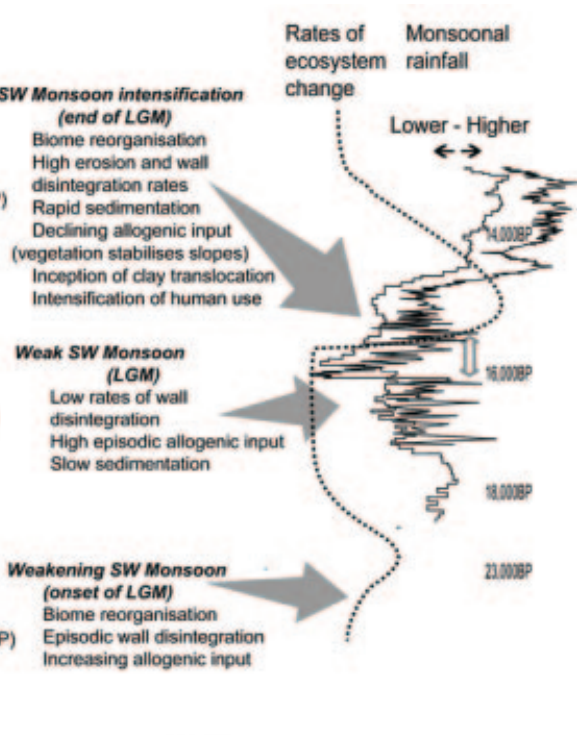

(c)

Figure 7. Working hypothesis that links the sediment record of Beli-lena with processes in the surrounding landscape. (a) Summary sedimentary record of Beli-lena; (b) inferred processes of sediment deposition in the rockshelter; (c) intensity of the Southwestern Monsoon (from $\delta^{18} \mathrm{O}$ records in speleothems from Hulu Cave, China: Wang et al., 2001), inferred rates of ecosystem change (smooth curve) and resulting geomorphic processes. Millennial fluctuation in the intensity of the Southwestern Monsoon controls rates of ecosystem change (highest in times of rapid change in monsoonal activity), which, in turn, affect rates of erosion and sediment mobilization along slopes. Some of this sediment finds its way into the rockshelter. Pulses of allogenic flux, most notably at ca. 15,700 cal B.P., correspond to such periods of monsoon-triggered ecosystem reorganization. In addition, sediment deposition is probably reinforced by accelerated roof and wall disintegration, partly as a result of human activity in the rockshelter. The white arrow indicates the possibility of temporal lags between mosoonal cue and ecosystem response. Such lags may account for declining allogenic input, as vegetation adjusts to the reinstated monsoonal regime and stabilizes slopes.

(Figure 7). The presence of discontinuities and the low resolution of rockshelter sediment records notwithstanding, this finding correlates remarkably well with highresolution isotopic records from both marine proxies (e.g., Arabian Sea sediment cores; Overpeck et al., 1996; Ivanochko et al., 2005) and speleothems from Hulu and Dongge caves, China (Wang et al., 2001; Yuan et al., 2004), and other tropical caves in the northern hemisphere (Lechniet, 2009), which suggest abrupt intensification of monsoonal activity ca. 16,000-14,000 cal B.P. Markedly higher deposition rates with high allogenic input in that period possibly reflect a synergy between roof fall, favored by increasing rainfall and human presence in the rockshelter, and mass movement around the site, with colluvial processes reworking part of the mobilized sediment into the rockshelter. Landsliding, known to occur at basin-wide, km scales in modern southwestern Sri Lanka and to correlate positively with both monsoonal rainfall and disruption of the forest biome by agricultural activity (Gunatilaka \& Almond, 2001; 
Gunatilaka, 2007), was probably a dominant process of sediment mobilization in the wider landscape during this period of monsoon recovery. Landsliding was probably favored by intensifying rainfall, rapid ecosystem reorganization, and the higher topographic gradients induced by the lower sea levels of the time (Voris, 2000; Lambeck \& Chappell, 2001).

We infer that most of phase IV deposition took place in the early stages of monsoonal intensification. Dramatically increased rates of roof fall and colluviation probably reflect the effects of monsoonal rainfall on bedrock and slopes covered by vegetation that reorganized rapidly as they adjusted to rapidly increasing rainfall and temperature. Indeed, if not an artifact of our reconnaissance-scale sampling, the observed decrease of allogenic input from phase IV to V could reflect such temporal lags between monsoonal cues and biome responses (Figure 7c). Rates of erosion upslope of the site, high during deposition of context IVb2, may have decreased as vegetation adjusted to post-LGM conditions in the following ca. 1000-1500 years. Increasing monsoonal activity during this period probably resulted in increased percolation of water through the sediment.

Human use of Beli-lena appears to have intensified in this period of accelerated environmental change. Similar evidence from Batadomba-lena (Figure 1b) suggests that intensification of rockshelter use in this period may have been a regional development among hunter-gatherer groups in inland southwestern Sri Lanka (Kourampas et al., 2008), broadly comparable with the intensified use of rockshelters in the rainforest throughout Southeast Asia some 5000 years later, in Early Holocene times (Anderson, 1997). Increased monsoonal rainfall during these times may have made rockshelters more attractive to human users. In addition to this, we postulate that the archaeological record reflects changing practices of foraging in the rainforest (cf. Barker et al., 2005, 2007), as human groups expanded into novel ecological niches shaped by environmental change. Human activity may have operated in synergy with increased rainfall and biome change to accelerate sedimentation in the rockshelter.

We cannot emphasize enough that this interpretation is laden with uncertainty, resulting from our inadequate understanding of sedimentary and landscape processes in the humid tropics, limited sampling of the profile, sketchy knowledge of the extrasite landscape, lithology, and soil cover (which could greatly facilitate identification of sediment provenance) and, crucially, scarcity of botanical evidence which could be the arbiter of our environmental inferences. Far from purporting to be conclusive, our interpretation is, accordingly, put forward as just one of the plausible working hypotheses afforded by our reading of the available data.

\section{CONCLUSIONS}

Late Pleistocene to Early Holocene (>31,000-7880 cal B.P.) archaeological deposits in the Kitulgala Beli-lena rockshelter comprise heterogeneous diamictic loams, breccias, and clays with variable cultural content, reflecting a complex interplay between episodic sedimentary processes, diverse human activity, and bioturbation by termites and other arthropods within an environment of active tropical weathering. 
Variable rates of roof fall, mass movement, and slope-wash events in the environs of the rockshelter, water seepage through the joint network, and the activities of Belilena's human occupants contributed mixtures of metamorphic bedrock clasts from disintegration of the rockshelter roof and walls, reworked saprolith and tropical soils from upslope, fine mineral material washed in from the overlying weathering mantle, and diverse human input, including tool-making refuse, reworked charcoal and other combustion by-products, and vegetable food remains. Sediments were reworked on the rockshelter floor by surface runoff, weathered by aggressive percolating fluids, and trampled by the site's human occupants. Sediment deposition was discontinuous, as evidenced by the presence of sharp boundaries between contexts, at least one ca. 21,000-year-old paleofloor, and extensive on-the-floor clast weathering, especially before and during the LGM.

The relative contribution of these depositional processes varied through time in the more than ca. 23,000 years represented by the sampled profile, resulting in a heterogeneous stratigraphy. Episodic roof fall and colluvial deposition ca. 25,000-20,000 cal B.P. is interpreted as reflecting increased climate seasonality and vegetation reorganization in the millennia leading to the LGM. LGM deposits were marked by low deposition rates and scarcity of roof fall, reflecting weakening of the Southwestern Monsoon. An abrupt increase in deposition rates, manifest through intensified roof fall and colluvial input in the millennium around ca. 15,700 cal B.P., reflects intensification of the Southwestern Monsoon and biome reorganization upslope of Belilena on the wane of the LGM. Human use of the rockshelter, which also appears to have intensified at that time, as elsewhere in inland southwestern Sri Lanka, possibly contributed to accelerated sediment deposition on the rockshelter floor. Periods of rapid sediment accumulation before and, especially, after culmination of the LGM were probably associated with an increased frequency of landslides in the surrounding landscape.

Post-depositional change included diachronous clay translocation, iron oxide mobilization and arthropod bioturbation. Ash dissolution by rockshelter floor fluids may account for the absence of ash deposits, which contrasts with the local presence of large quantities of charcoal. An almost total absence of microscopic bone fragments contrasts sharply with the abundance of macroscopic bone and raises the possibility of post-depositional bone dissolution. Translocation of inferred phosphates across the profile was minor and mainly concentrated in the earlier part of the profile, older that 15,700 cal B.P.

Bioturbation by arthropod fauna, including soil-dwelling termites, is present throughout the sampled profile. Bioturbation is especially marked in sediments with high charred organic content. One sampled context represents colluvium resulting from the disintegration of an Early Holocene (?) termite and/or ant nest.

This work demonstrates the relevance of Sri Lanka's rockshelter sites to broader debates regarding past human societies in the low-latitude world. A systematic program of environmental archaeology in Sri Lanka, coupled with actualistic research that aims to document processes of human-induced deposition in tropical settings, can make significant contributions to our understanding of human behavior, ecology, and environmental change in Late Pleistocene South Asia. 
We are indebted to the Sri Lankan Department of Archaeology for their outstanding field support. We are also grateful to Ananda Gunatilaka, Ana Polo Diaz, Jo McKenzie, and Krista Gilliland for their advice and comments on earlier versions of this paper. Constructive criticism and suggestions by Jamie Woodward, Mark Stephens, and two anonymous reviewers helped us improve the manuscript. Thin sections were manufactured by George MacLeod (University of Stirling). A British Academy grant to Ian Simpson funded part of this work.

\section{REFERENCES}

Anderson, D.D. (1997). Cave archaeology in Southeast Asia. Geoarchaeology, 12, 607-638.

Anhuf, D., Ledru, M.-P., Behling, H., Da Cruz Jr., F.W., Cordeiro, R.C., Van der Hammen, T., Karmann, I., Marengo, J.A., De Oliveira, P.E., Passenda, L., Siffedine, A., Albuquerque, A.L., \& Da Silva Dias, P.L. (2006). Paleo-environmental change in Amazonian and African rainforest during the LGM. Palaeogeography, Palaeoclimatology, Palaeoecology, 239, 510-527.

Barker, G., Reynolds, T., \& Gilbertson, D. (2005). The human use of caves in peninsular and island Southeast Asia: Research themes. Asian Perspectives, 44, 1-15.

Barker, G., Barton, H., Bird, M., Daly, P., Datan, I., Dykes, A., Farr, L., Gilbertson, D., Garrisson, B., Hunt, C., Higham, T., Kealhofer, L., Krigbaum, J., Lewis, H., McLaren, S., Paz, V., Pike, A., Piper, P., Pyatt, B., Rabett, R., Reynolds, T., Rose, J., Rushworth, G., Stephens M., Stringer, C., Thompson, J., \& Turney, C. (2007). The "human revolution" in lowland tropical Southeast Asia: The antiquity and behavior of anatomically modern humans at Niah Cave (Sarawak, Borneo). Journal of Human Evolution, 52, 243-261.

Bird, M.I., Taylor, D., \& Hunt, C. (2005). Palaeoenvironments of insular Southeast Asia during the Last Glacial Period: A savanna corridor in Sundaland? Quaternary Science Reviews, 24, 2228-2242.

Bird, M.I., Boobyer, E.M., Bryant, C., Lewis, H., Paz, V., \& Stephens, W.E. (2007). A long record of environmental change from bat guano deposits in Makangit Cave, Palawan, Philippines. Earth and Environmental Science Transactions of the Royal Society of Edinburgh, 98, 59-69.

Birkeland, P.W. (1984). Soils and geomorphology. Oxford: Oxford University Press.

Bremer, H. (1985) Soil and slope development in the wet zone of Sri Lanka. In I. Douglas \& T. Spencer (Eds.), Environmental change and tropical geomorphology (pp. 295-301). British Geomorphological Research Group. London: Allen \& Unwin.

Bremer, H., Schnütgen, A., Späth, H., Tillmanns, W., Symander, W., \& Stein, W. (Eds.). (1981). Zur Morphogenese in den feuchten Tropen. Verwitterung und Reliefbildung am Beispiel von Sri Lanka. Relief Boden Paläoklima 1. Berlin: Gerbrüder Borntraeger.

Bulbeck, D., Rayner, D., Groves, C., \& Pathmanathan, R. (2003). The contribution of South Asia to the peopling of Australasia and the relevance of Basel's Naturhistorisch Museum anthropological collection to the project aims. Bulletin de Societé Suisse d'Anthropologie, 9, 49-70.

Bullock, P., Fedoroff, N., Jongerius, A., Stoops, G., Tursina, T., \& Babel, U. (1985). Handbook for soil thin section description. Albrington: Waine Research Publications.

Butzer, K.W. (1981). Cave sediments, Upper Pleistocene stratigraphy and Mousterian facies in Cantabrian Spain. Journal of Archaeological Science, 8, 133-183.

Collins, N.M. (1989). Termites. In H. Lieth \& M.J.A. Werger (Eds.), Tropical rain forest ecosystems: Biogeographical and ecological studies (pp. 455-469). Amsterdam: Elsevier.

Cooray, P.G. (1984). The geology of Sri Lanka. Colombo: National Museum Publications.

Courty, M.A. (1986) Quelques faciès d'altération de fragments carbonatés en grottes et abris sous roches préhistoriques. Bulletin de l'Association française pour l'etude du Quaternaire, 3/4, 282-289.

Courty, M.A. (2001) Microfacies analysis assisting archaeological stratigraphy. In P. Goldberg, V.T. Holliday, \& C.R. Ferring (Eds.), Earth sciences and archaeology (pp. 205-239). New York: Kluver.

Courty, M.A., \& Vallverdú, J. (2001) The microstratigraphic record of abrupt climate changes in cave sediments of the western Mediterranean. Geoarchaeology, 16, 467-500.

Courty, M.A., Goldberg, P., \& Macphail, R. (1989). Soils and micromorphology in archaeology. Cambridge: Cambridge University Press.

Cosarinski, M.I., \& Roces, F. (2007) Neighbor leaf-cutting ants and mound-building termites: Comparative nest micromorphology. Geoderma, 141, 224-234. 
Dalrymple, J.B., \& Theocharopoulos, S.P. (1984). Intrapedal cutans: Experimental production of depositional cutans (illuviation) channel argillans. Geoderma, 33, 237-243.

Davidson, D.A., \& Simpson, I. (2001). Archaeology and soil micromorphology. In D.R. Brothwell \& A.M. Pollard (Eds.), Handbook of archaeological sciences (pp. 167-177). Chichester: Wiley.

Dejean, A., Bolton, B., \& Durand, J.L. (1997). Cubitermes subarquatus termitaries as shelters for soil fauna in African rainforests. Journal of Natural History, 31, 1289-1302.

Delvigne, J.E. (1998). Atlas of micromorphology of mineral alteration and weathering. The Canadian Mineralogist Special Publication 3. Ottawa: Mineralogical Association of Canada.

Deraniyagala, S.U. (1992). The prehistory of Sri Lanka: An ecological perspective, Parts I and II. Colombo: Department of Archaeological Survey, Government of Sri Lanka.

Domrös, M. (1974). The agroclimate of Ceylon: A contribution towards the ecology of tropical crops. Wiesbaden: Franz Steiner.

Endicott, P., Metspalu, M., \& Kivisild, T. (2007). Genetic evidence on modern human dispersals in South Asia: Y chromosome and mitochondrial DNA perspectives: The world through the eyes of two haploid genomes. In M.D. Petraglia \& B. Allchin (Eds.), The evolution and history of human populations in South Asia: Interdisciplinary studies in archaeology, biological anthropology, linguistics and genetics (pp. 229-244), Dordrecht: Springer.

Field, J.S., Petraglia, M.D., \& Lahr, M.M. (2007). The southern dispersal hypothesis and the South Asian archaeological record: Examination of dispersal routes through GIS analysis. Journal of Anthropological Archaeology, 26, 88-108.

Gaussen, H., Legris, P., Viart, M., \& Labroue, L. (1968). Explanatory notes on the vegetation map of Ceylon. Colombo: Government Press.

Geological Survey and Mines Bureau. (1996). Colombo-Ratnapura (1:100,000). Colombo: Geological Survey and Mines Bureau.

Gifford-Gonzalez, D.P., Damrosch, D.B., Damrosch, D.R., Pryor, J., \& Thunen, R.L. (1985). The third dimension in site structure: An experiment in trampling and vertical dispersal. American Antiquity, 50, 803-818.

Gilbertson, D., Bird, M., Hunt, C., McLaren, S., Mani Banda, R., Pyatt, B., Rose, J., \& Stephens, M. (2005). Past human activity and geomorphological change in a guano-rich tropical cave mouth: Initial interpretations of the Late Quaternary succession in the Great Cave of Niah, Sarawak. Asian Perspectives, $44,16-41$.

Gillieson, D. (1996). Caves: Processes, development and management. Oxford: Blackwell.

Gillieson, D., Oldfield, F., \& Krawiecki, A. (1986). Soil erosion from rock-shelter sites in Papua New Guinea. Mountain Research and Development, 6, 315-324.

Goldberg, P., \& Macphail, R.I. (2006). Practical and theoretical geoarchaeology. Oxford: Blackwell.

Goldberg, P., \& Sherwood, S.C. (2006). Deciphering human prehistory through the geoarcheological study of cave sediments. Evolutionary Anthropology, 15, 20-36.

Greenway, D.R. (1987). Vegetation and slope stability. In M.G. Anderson \& K.S. Richards (Eds.), Slope stability (pp. 187-230), Chischester: Willey.

Gunatilaka, A. (2000). Sea-levels as historical time-markers in prehistoric studies. Journal of the Royal Asiatic Society of Sri Lanka, 45, 19-34.

Gunatilaka, A. (2007). Role of basin-wide landslides in the formation of extensive alluvial gemstones in Sri Lanka. Earth Surface Processes and Landforms, 32, 1863-1873.

Gunatilaka, A., \& Almond, D.C. (2001). Serendipity and the jewels of Serendib: Part 2. External processes and climatic framework that influenced the genesis of the multi-species gemstone province in Sri Lanka. Journal of the Geological Society of Sri Lanka, 10, 49-67.

Gupta, A.K., Anderson, D.M., \& Overpeck J.T. (2003). Abrupt changes in the Asian southwest monsoon during the Holocene and their links to the North Atlantic Ocean. Nature, 421, 354-357.

Hansen, J. (2001). Macroscopic plant remains from Mediterranean caves and rockshelters: avenues of interpretation. Geoarchaeology, 16, 401-432.

Harwood, G. (1988). Microscopic techniques: II. Principles of sedimentary petrography. In M. Tucker (Ed.) Techniques in sedimentology (pp. 108-173), Oxford: Blackwell.

Hawkey, D.A. (2003). The peopling of South Asia: Evidence for affinities in microevolution of prehistoric populations of India and Sri Lanka. Spolia Zeylandica 39. Colombo: National Museums Department. 
Hunt, C.O., Gilbertson, D.D., \& Rushworth, G. (2007). Modern humans in Sarawak, Malaysian Borneo, during oxygen isotope stage 3: Palaeonvironmental evidence from the Great Cave of Niah. Journal of Archaeological Science, 34, 1953-1969.

Ivanochko, T.S., Ganeshram, R.S., Brummer, G.-J.A., Ganssen, G., Jung, S.J.A., Moreton, S.G., \& Kroon, D. (2005). Variations in tropical convection as an amplifier of global climate change at the millennial scale. Earth and Planetary Science Letters, 235, 302-314.

Jackson, S.T., \& Overpeck, J.T. (2000). Responses of plant populations and communities to environmental changes of the late Quaternary. Palaeobiology, 26, 194-220.

James, H.V.A. (2007). The emergence of modern human behaviour in South Asia: A review of the current evidence and discussion of the possible implications. In M.D. Petraglia \& B. Allchin, (Eds.), The evolution and history of human populations in South Asia: Interdisciplinary studies in archaeology, biological anthropology, linguistics and genetics (pp. 268-281). Dordrecht: Springer.

Jungerius, P.D., van der Anker, J.A.M., \& Mücher, H.J. (1999). The contribution of termites to the microgranular structure of soils on the Uasin Gishu Plateau, Kenya. Catena, 34, 349-363.

Kajale, M.D. (1989). Mesolithic exploitation of wild plants in Sri Lanka: Archaeobotanical study at the cave site of Beli-Lena. In D.R. Harris \& G.C. Hillman (Eds.), Foraging and farming: The evolution of plant exploitation (pp. 268-281). London: Unwin Hyman.

Karkanas, P. (2001). Site formation processes in Theopetra Cave: A record of climatic change during the Late Pleistocene and Early Holocene in Thessaly, Greece. Geoarchaeology, 16, 373-399.

Karkanas, P., Bar-Yosef, O., Goldberg, P., \& Weiner, S. (2000). Diagenesis in prehistoric caves: The use of minerals that form in situ to assess the completeness of the archaeological record. Journal of Archaeological Science, 27, 915-929.

Karkanas, P., Kyparissi-Apostolika, N., Bar-Yosef, O., \& Weiner, S. (1999). Mineral assemblages in Theopetra, Greece: A framework for understanding diagenesis in a prehistoric cave. Journal of Archaeological Science, 26, 1171-1180.

Karkanas, P., Rigaud, J.-P., Simek, J.F., Albert, R.M., \& Weiner, S. (2002). Ash, bones and guano: A study of the minerals and phytoliths in the sediments of Grotte XVI, Dordogne, France. Journal of Archaeological Science, 29, 721-732.

Kennedy, K.A.R. (1999). Paleoanthropology of South Asia. Evolutionary Anthropology, 8, 165-185.

Kennedy, K.A.R., \& Deraniyagala, S.U. (1989). Fossil remains of 28,000-year-old hominids from Sri Lanka. Current Anthropology, 30, 394-399.

Kennedy, K.A.R., Deraniyagala, S.U., Roertgen, W.J. Chiment, J., \& Disotell, T. (1987). Upper Pleistocene fossil hominids from Sri Lanka. American Journal of Physical Anthropology, 72, 441-461.

Kourampas, N., Simpson, I.A., Perera , H.N., \& Deraniyagala, S.U. (2008). Late Pleistocene huntergatherers in the South Asian rainforest: Geoarchaeology of inhabited rockshelters in south-western Sri Lanka. Antiquity, 82. Available at: http://antiquity.ac.uk/Projgall/kourampas/index.html.

Lachniet, M.S. (2009). Climatic and environmental controls on speleothem oxygen isotope values. Quaternary Science Reviews, 28, 412-432.

Lambeck, K., \& Chappell, J. (2001). Sea level change through the last glacial cycle. Science, 292, 679-686.

Laville, H., Rigaud, J.Ph., \& Sackett, J. (1980). Rockshelters of the Périgord. Geological stratigraphy and Archaeological Succession. London: Academic Press.

Leushner, D.C., \& Sirocko, F. (2000). The low-latitude monsoon climate during Dansgaard-Oeschger cycles and Heinrich Events. Quaternary Science Reviews, 19, 243-254.

Lewis, H. (2007). Preliminary soil micromorphology studies of landscape and occupation history at Tabon Cave, Palawan, Philippines. Geoarchaeology, 22, 685-708.

Lewis, H., Paz, V., Lara, M., Barton, H., Piper, P., Ochoa, J., Vitales, T., Carlos, J., Higham, T., Neri, L., Hernandez, V., Stevenson, J., Robles, E., Ragragio, A., Padilla, R., Solheim, W., II, \& Ronquillo, W. (2008). Terminal Pleistocene to mid Holocene occupation and an early cremation burial at Ille Cave, Palawan, Philippines. Antiquity, 82, 318-335.

McBrearty, S. (1990) Consider the humble termite: Termites as agents of post-depositional disturbance at African archaeological sites. Journal of Archaeological Science, 17, 111-143.

Mellars, P. (2006). Going east: New genetic and archaeological perspectives on the modern human colonization of Eurasia. Science, 313, 796-800. 
Mercader, J. (2002). Forest people: The role of African rainforests in human evolution and dispersal. Evolutionary Anthropology, 11, 117-124.

Mercader, J., Martí, R., González, I., Sánchez, A., \& García, P. (2003). Archaeological site formation in rain forests: Insights from the Ituri rockshelters, Congo. Journal of Archaeological Science, 30, 45-65.

Moeyersons, J. (1997). Geomorphological processes and their palaeoenvironmental significance in the Shum Laka cave (Bamenda, western Cameroon). Palaeogeography, Palaeoclimatology, Palaeoecology, $133,103-116$.

Oppenheimer, S. (2003) Out of Eden: The peopling of the world. London: Robinson.

Overpeck, J., Anderson, D., Trumbore, S., \& Prell, W. (1996). The southwest Indian Monsoon over the last 18000 years. Climate Dynamics, 25, 213-225.

Perera, H.N. (in press). Prehistoric Sri Lanka: Late Pleistocene rockshelters and open-air site. Oxford: BAR International Series.

Pope, K.O., \& Terrell, J.E. (2008). Environmental setting of human migrations in the circum-Pacific region. Journal of Biogeography, 35, 1-21.

Premathilake, R., \& Risberg, J. (2003). Late Quaternary history of the Horton Plains, central Sri Lanka. Quaternary Science Reviews, 22, 1525-1541.

Sémah, F., Sémah, A.-M., Falguéres, C., Dètroit, F., Simanjuntak, T., Moigne, A.-M., Gallet, X., \& Hameau, S. (2004). The significance of the Punung karstic area (Eastern Java) for the chronology of the Javanese Palaeolithic, with special reference to the Song Terus cave. Modern Quaternary Research in Southeast Asia, 19, 45-61.

Sergant, J., Crombé, P, \& Perdaen, Y. (2006). The "invisible" hearths: A contribution to the discernment of Mesolithic non-structured surface hearths. Journal of Archaeological Science, 33, 999-1007.

Shahack-Gross, R., Berna, F., Karkanas, P., \& Weiner, S. (2004). Bat guano and preservation of archaeological remains in cave sites. Journal of Archaeological Science, 31, 1259-1272.

Simpson, I.A., Kourampas, N., \& Perera, H.N. (2008). Bellan-Bandi Palasa, Sri Lanka: Formation processes of a Mesolithic open-air site identified through thin-section micromorphology. Archaeologia: Journal of Archaeology, 4, 3-18.

Stephens, M., Rose, J., Gilbertson, D., \& Canti, M.G. (2005). Micromorphology of cave sediments in the humid tropics: Niah Cave, Sarawak. Asian Perspectives, 44, 42-55.

Stoops, G. (2003). Guidelines for analysis and description of soil and regolith thin sections. Madison, WI: Soil Science Society of America.

Stott, L., Poulsen, C., Lund, S., \& Thunell, R. (2002). Super ENSO and global climate oscillations at millennial time scales. Science, 297, 222-226.

Thamban, M., Purnachandra Rao, V., \& Schneider, R.R. (2002). Reconstruction of late Quaternary monsoon oscillations based on clay mineral proxies using sediment cores from the western margin of India. Marine Geology, 186, 527-539.

Theocharopoulos, S.P., \& Dalrymple, J.B. (1987). Experimental construction of illuviation cutans (channel argillans) with differing micromorphological and optical properties. In N. Fedoroff, L.M. Bresson, \& M.A. Courty (Eds.), Micromorphologie des sols [Soil micromorphology] (pp. 245-250). Plaisir: AFES.

Thomas, M.F. (1994). Geomorphology in the tropics: A study of weathering and denudation in low latitudes. Chichester: Wiley.

Voris, H.K. (2000). Maps of Pleistocene sea levels in Southeast Asia: Shorelines, river systems and time durations. Journal of Biogeography, 27, 1153-1167.

Wang, Y.J., Cheng, H., Edwards, R.L., An, Z.S., Wu., J.Y., Shen, C.-C. and Dorale, J.A. (2001). A highresolution absolute-dated late Pleistocene monsoon record from Hulu Cave, China. Science, 294, 2345-2348.

Ward, I.A.K., Fullagar, R.L.K., Boer-Mah, T., Head, L.M., Taçon, P.S.C., \& Mulvaney, K. (2006). Comparison of sedimentation and occupation histories inside and outside rock shelters, Keep-River region, Northwestern Australia. Geoarchaeology, 21, 1-27.

Weiner, S., Goldberg, P., \& Bar-Yosef, O. (1993). Bone preservation in Kebara Cave using on-site Fourier transform infrared spectrometry. Journal of Archaeological Science, 20, 613-627.

Wijeyapala, W.H. (1997). New light on the prehistory of Sri Lanka in the context of recent investigations of cave sites. Unpublished doctoral dissertation, University of Peradiniya, Peradiniya. 
Woodward, J. (1997a). Late Pleistocene rockshelter sedimentation at Klithi. In G. Bailey (Ed.), Klithi: Palaeolithic settlement and Quaternary landsapes in northwest Greece, Vol. 2 (pp. 361-376). Cambridge: McDonald Institute for Archaeological Research.

Woodward, J. (1997b). Late Pleistocene rockshelter sedimentation at Megalakkos. In G. Bailey (Ed.), Klithi: Palaeolithic settlement and Quaternary landsapes in northwest Greece, Vol. 2 (pp. 377-393). Cambridge: McDonald Institute for Archaeological Research.

Woodward, J.C., \& Bailey, G.N. (2000). Sediment sources and terminal Pleistocene geomorphological processes recorded in rockshelter sequences in northwest Greece. In I.D.L. Foster (Ed.), Tracers in geomorphology (pp. 521-551). Chichester: Wiley.

Woodward, J.C., \& Goldberg, P. (2001). The sedimentary records in Mediterranean rockshelters and caves: Archives of environmental change. Geoarchaeology, 16, 327-354.

Woodward, J.C., \& Morley, M. (2008). The clastic sedimentary record in rockshelters and caves: Problems and prospects. 6th World Archaeology Conference, Dublin, p. 142.

Yuan, D., Cheng, H., Edwards, R.L., Dykoski, C.A., Kelly, M.J., Zhang, M., Qing, J., Lin, Y., Wang, Y., Wu, J., Doralle, J.A., An, Z., \& Cai, Y. (2004). Timing, duration, and transitions of the Last Interglacial Asian Monsoon. Science, 304, 575-578.

Received 15 July 2009

Accepted for publication 28 July 2009

Scientific editing by Jamie Woodward 